Published in final edited form in Advances in Experimental Medicine and Biology. Springer, New York, NY at https://doi.org/10.1007/5584_2018_241.

\title{
Molecular mechanisms of vaspin action - from adipose tissue to skin and bone, from blood vessels to the brain
}

\author{
Juliane Weiner ${ }^{1,2,{ }^{*}}$, Konstanze Zieger ${ }^{1,}{ }^{*}$, Jan Pippel ${ }^{3}$ and John T. Heiker ${ }^{1,2}$ \\ ${ }^{1}$ Institute of Biochemistry, Faculty of Life Sciences, University of Leipzig, Germany \\ 2 Department of Medicine, University of Leipzig, Germany \\ ${ }^{3}$ Structure and Function of Proteins, Helmholtz Centre for Infection Research, Braunschweig, \\ Germany
}

*contributed equally

To whom correspondence should be addressed:

John T. Heiker, Institute of Biochemistry, Faculty of Life Sciences, University of Leipzig, Bruederstr. 34, 04103 Leipzig, Germany, Tel.: +49-341-9736990, Fax: +49-341-9736909, Email: jheiker@uni-leipzig.de

word count: number of tables and figures: 


\section{Abstract}

Visceral adipose tissue-derived serine protease inhibitor (vaspin) or SERPINA12 according to the serpin nomenclature was identified together with other genes and gene products that were specifically expressed or overexpressed in the intra-abdominal or visceral adipose tissue (AT) of the Otsuka Long-Evans Tokushima fatty rat. These rats spontaneously develop visceral obesity, insulin resistance, hyperinsulinemia and-glycemia, as well as hypertension and thus represent a well suited animal model of obesity and related metabolic disorders such as type 2 diabetes.

The follow-up study reporting the cloning, expression and functional characterization of vaspin suggested the great and promising potential of this molecule to counteract obesity induced insulin resistance and inflammation and has since initiated over 300 publications, clinical and experimental, that have contributed to uncover the multifaceted functions and molecular mechanisms of vaspin action not only in the adipose, but in many different cells, tissues and organs. This review will give an update on mechanistic and structural aspects of vaspin with a focus on its serpin function, the physiology and regulation of vaspin expression, and will summarize the latest on vaspin function in various tissues such as the different adipose tissue depots as well as the vasculature, skin, bone and the brain.

Key words: adiposity, atherosclerosis, crystal structure, exosite, inflammation, insulin resistance, metabolic syndrome, serine proteases, serpin

Abbreviations: KLK7, kallikrein 7; AT, adipose tissue; HFD, high-fat diet; ATM, adipose tissue macrophage; MMP, matrix metalloproteinase, T2D, type 2 diabetes; DHEA-S, dehydroepiandrosterone sulfate; $\mathrm{CRH}$, Corticotropin-releasing Hormone; CART Cocaine and amphetamine-regulated transcript; NMDA, N-Methyl-D-aspartat 


\section{Vaspin structure and inhibition mechanism}

\subsection{Serpin mechanism}

Based on a sequence homology of $\sim 40 \%$ with anti-trypsin, vaspin was proposed to belong to the serpin family [1]. The name serpin refers to the main function of this family as specific serine protease inhibitors (reviewed in [2]). The fold of inhibitory serpins is highly conserved and consists of three $\beta$-sheets $(A-C)$, nine $\alpha$-helices and, at the top of the molecule, a flexible, cleavable reactive center loop ( $R C L$ ) which contains the protease recognition sequence. As a specific feature of the native state of inhibitory serpins, the central $\beta$-sheet $A$ is composed of five $\beta$-strands [3].

To initiate the inhibition reaction, the target protease recognizes its specific sequence in the $\mathrm{RCL}$ to form the non-covalent Michaelis complex. This orients the $\mathrm{RCL}$ into the active site of the target protease with the scissile bond (between $\mathrm{P} 1$ and $\mathrm{P} 1^{\prime}$ ) located in close proximity to the catalytic triad. Additional to interactions of the RCL with the target protease, the complex can also be stabilized by interactions outside the active site. Such interactions are referred to as exosites which are exploited by serpins to refine their specificity as well as to enhance their inhibition rate towards respective target proteases and can even compensate for possible detrimental effects resulting from an unfavorable RCL sequence (reviewed in [4]).

Hydrolysis of the peptide bond is initiated by the acylation reaction during which a covalent acyl-enzyme intermediate is formed between the catalytically active serine of the target protease and residue P1 which constitutes the N-terminal fragment of the now cleaved RCL. Before the reaction cycle is completed via the subsequent deacylation reaction, the $R C L$ performs a fast movement and incorporates into the central $\beta$-sheet $A$ as the sixth strand $[5,6]$. Simultaneously, the RCL-bound protease is delocalized from the top of the serpin to the bottom by approximately $70 \AA$ [7]. As a consequence of the inhibition mechanism, the reactive center is severely distorted which prevents dissociation of the covalent complex $[8,9]$. Additionally, more distant parts of the target protease might become disordered [8], making the complex susceptible to proteolytic digestion $[10,11]$. In vivo, serpin-enzyme-complex (SEC) receptors located on the cell surface can bind serpin-protease complexes and mediate clearance from the circulation $[12,13]$.

As the movement of the $R C L$ is not reversible, the serpin inhibition mechanism represents a suicide-substrate mechanism [14]. Thus, the protease may escape inhibition, if the peptide bond is hydrolyzed before the RCL is completely incorporated. For very efficient inhibition reactions the stoichiometry of inhibition is $\sim 1$, while for other more substrate-like reactions the $\mathrm{SI}$ is $>1$, and the $\mathrm{SI}$ represents an additional regulatory aspect to fine-tune protease activity 
[2]. Serpins might also behave as substrate as a result of mutations which impede efficient and fast RCL incorporation $[15,16]$. For vaspin, mutants T365R and A369P represent noninhibitory variants [17] and our data indeed revealed that RCL insertion is significantly slowed down but still takes place [18].

\subsection{Crystal structures of native and cleaved vaspin}

To further elucidate the molecular mechanism underlying vaspin protease specificity and regulation of inhibitory action, four different crystal structures of human vaspin have been determined. This includes structures of the wt [17] and two mutants (E379S and D305C/V383C) [19] in the native uncleaved state as well as of the wt in the cleaved state [18]. Notably, rat and murine vaspin share high sequence identities with the human protein $(61.5 \%$ or $62.6 \%$ amino acid identity, respectively) and thus conclusions drawn from structures of human vaspin are likely relevant and true for the rodent vaspin proteins as well. The same holds true for known important residues and protein domains that will be discussed in the following paragraphs (e.g. RCL and cleavage site, exosites and heparin binding site) and which are also conserved in mouse and rat vaspin.

The structures of vaspin in the native state display the highly conserved structural elements of inhibitory serpins with a largely unresolved flexible RCL [3] (Figure 1A). However, compared to most other crystal structures of inhibitory serpins, the C-terminal part of the RCL (T375 E379; residues $\mathrm{P} 4-\mathrm{P} 1^{\prime}$ including the protease cleavage site) is defined by electron density and appears more rigid. The vaspin RCL is cleaved between M378 (P1) and E379 (P1') as described in more detail below [17]. In the native structure, residues E379 (P1') and T380 (P2') of the $\mathrm{RCL}$ interact with $\mathrm{R} 302$ of $\beta$-sheet $\mathrm{C}$ via a salt bridge and a water-mediated hydrogen bond, respectively. By manipulation of the $R C L$ sequence via introduction of a serine at P1' (E379S) and an artificial disulfide bridge in proximity to the scissile bond (D305C/V383C), the flexibility of the C-terminal part of the RCL was enhanced as shown in the crystal structures.

An inherent feature of serpins in the native inhibitory state is their "poised ready" metastable conformation [20] which provides the basis for the tremendous conformational changes during transition into the thermodynamically favored RCL-cleaved state [21-23]. The fold of $\mathrm{RCL}$-cleaved serpins is also highly conserved and resembles that of the protein in the covalent complex [8,9]. The crystal structure of cleaved vaspin was determined in 2016 [18].

Common to other structures of cleaved serpins, the $\mathrm{N}$-terminal part of the RCL now makes a turn in the so called hinge region (residues P15 - P9) and joins the central $\beta$-sheet $A$ as an additional strand (Figure 1B, lower box) whereas the C-terminal cleavage site residues remain 
flexible and are thus partially unresolved in the crystal structure (Figure 1B, upper box). The hinge region in serpins comprises a highly conserved GTEGAAx ${ }_{1}$ T sequence (P15 - P8; $\mathrm{G}_{364}$ TEGAAGT $_{371}$ for vaspin) which is fundamental for the observed conformational mobility [24]. Additionally, residues of the breach region, which is located at top of $\beta$-sheet $A$ and is the point of initial strand insertion, form a number of partially conserved interactions with hinge region residues described further below in more detail. Mutations in both regions mostly have adverse effects on the inhibitory activity of serpins $[25,26]$. In contrast, residues $372-378$ (P7 - P1) are not conserved among inhibitory serpins and accordingly, the environment of these amino acids is less constrained in vaspin with $M 378$ (P1) as the last residue of the inserted strand being solvent exposed (Figure 1B, lower box) [18].

The metastable nature of inhibitory serpins allows these proteins to undergo large conformational changes but on the other hand makes them prone to inactivation by polymerization or latency transition without prior cleavage of the RCL. In these states, the RCL is not accessible for the target proteases, resulting in non-inhibitory serpins [27]. In contrast to several other human inhibitory serpins, native vaspin represents a remarkably thermostable serpin with only little tendency towards these inactivation mechanisms $[19,18]$. In this regard, key features in the breach and hinge region were identified which may support this behavior and the most noticeable will be described in the following. As mentioned above, the breach region is located at the upper part of s3A and s5A and in vaspin, recalls the picture of a 'partial opened zipper'. In this region, a conserved $F K G x_{1} W x_{2} X_{3} X_{4} F$ sequence ( $F_{210}$ RARWKHEF 218 for vaspin) forms a prominent surface groove in which residues R363 E366 (P16 - P13) of the RCL hinge region are rigidly embedded (Figure 1A, middle box). This may prevent latency transition or polymerization of native vaspin. In both, the native and the RCL-cleaved state, R310 forms a salt bridge with E362 (P17) such that E362 determines the end of s5A and provides a hinge point for insertion of the new S4A (Figure 1A, middle box, Figure 1B, middle box). E362 is strictly conserved among inhibitory serpins and mutation of this residue (E342K, Z-variant) is responsible for $95 \%$ of all clinically recognized $\alpha_{1}$-antitrypsin $\left(\alpha_{1} A T\right)$ deficiency cases [28]. The acute-phase protein $\alpha_{1} A T$ is produced mainly in the liver and functions as a major inhibitor of various proinflammatory proteases such as neutrophil elastase or cathepsin G. The Z-variant of $\alpha_{1} A T$ is prone for misfolding, latency and polymerization and is associated with cirrhosis or hepatocellular carcinoma [29]. Furthermore, R363 (P16) interacts with D361 and this salt bridge may prevent pre-insertion of the RCL into the open void between s3A and s5A (Figure 1A, middle box) in the native state of vaspin [18]. However, until now, we can only speculate whether these interactions play major roles in the 
remarkable thermostability of vaspin and respective follow-up studies are necessary to verify our hypothesis.

\subsection{Tested and Targeted Proteases}

The finding of $\sim 40 \%$ sequence identity of vaspin with the bona-fide serpin anti-trypsin suggested affiliation with the large serpin family of proteinase inhibitors and initiated the search for target proteases, as these (in addition to the serpin itself) represent promising, potentially new and direct drug targets which may lead to novel therapeutic strategies for the treatment of obesity and its related metabolic and cardiovascular diseases [30,31].

Vaspin did not inhibit well-known serine proteases, such as trypsin, elastase, urokinase, factor Xa, collagenase and dipeptidyl peptidase [32]. We later screened selected members of the kallikrein family (KLKs) and we found KLK7 to be inhibited by vaspin via the classical serpin mechanism. The closely related kallikreins KLK4 and 5 were not inhibited [17]. KLK7 is a chymotryptic serine protease that was initially identified in skin where it is involved in the skin desquamation process [33] and aberrant activity of KLK7 is related to the pathogenesis of inflammatory skin diseases such as psoriasis [34] and acne rosacea [35]. Furthermore, the trypsin- and chymotrypsin-like protease KLK14 was recently identified as the second member of the kallikrein family that is targeted by vaspin [36]. KLK14, together with the main players in KLK7 and KLK5, is also involved in skin desquamation [37].

\subsection{Determinants of specificity - RCL sequence and exosites for KLK7 inhibition}

The scissile bond within the vaspin $\mathrm{RCL}$ is located between a methionine and a glutamate residue and this $\mathrm{P}^{\prime}$ glutamate stands out when investigating potential protease targets of vaspin, as it is a highly unusual residue at this position and likely determining protease specificity. Measuring the inhibition kinetics for KLK7 by vaspin revealed a rather slow inhibition reaction with a second order rate $\left(k_{i}\right)$ of $7.3 \times 10^{3} \mathrm{M}^{-1} \mathrm{x} \mathrm{s}^{-1}$, when compared with $k_{i}$ values in the range of $10^{6} \mathrm{M}^{-1} \mathrm{x} \mathrm{s}^{-1}$ for other serpin-protease pairs [17].

Using a synthetic combinatorial peptide library, Debela et al. investigated the S4-S1 specificity of KLK7 and demonstrated chymotryptic-like specificity with a preference for the residues Tyr, Ala and Met at the P1 position (in that order) [38]. The KLK7 specificity profile was expanded by Oliviera et al. to the S1'-S3' sites using soluble FRET peptide libraries. This study confirmed Tyr residues to be preferred at P1 and the preference for hydrophilic amino acids, particularly Arg at P1' [39]. These data implicate the vaspin RCL sequence of TPM-ETP (from P3 to P3') as a rather unfavorable cleavage site. Indeed, a peptide comprising the $\mathrm{RCL}$ sequence is not 
cleaved by KLK7 [19]. In line with these findings, the E379S mutant with a more favored serine residue in P1 has a significantly increased $k_{i}$ value of $4 \times 10^{5} \mathrm{M}^{-1} \times \mathrm{s}^{-1}$ for KLK7 [19]. These data clearly demonstrate that $\mathrm{E} 379$ is the major negative regulatory element purposely limiting the rate of inhibition while also increasing specificity. This seems of great importance with respect to the low serum levels and distinct expression pattern of vaspin.

As discussed above, in the crystal structure of native vaspin we were intrigued by a potential ionic interaction between the $\mathrm{P} 1^{\prime}$ residue $\mathrm{E} 379$ and $\mathrm{R} 302$, which is located in close proximity of the RCL. This interaction resulted in a rather constraint C-terminal part or the RCL including the cleavage site. With the intention to increase flexibility of the RCL, we mutated R302 but found these vaspin mutants, R302A and R302E, to be fully inactive. In contrast to inactive substrate mutants vaspin A369P or T365R [17], these mutants were not cleaved by KLK7, indicating R302 as an essential exosite, enabling KLK7 inhibition and further ensuring specificity [19]. In addition to the positive exosite R302, the negatively charged D305 in close proximity to the RCL is suppressing KLK7 inhibition, as the mutant D305A exhibits an 8-fold increase in inhibition rate [36]. The second protease KLK14 has the same cleavage site within the vaspin RCL (after M378) and is inhibited with a ki value of $1 \times 10^{3} \mathrm{M}^{-1} \times \mathrm{s} \mathrm{s}^{-1}$. Interestingly, inhibition of KLK14 is not dependent on the exosites that enable or regulate KLK7 inhibition (R302 and D305, respectively) [36].

Very likely, further exosites are contributing to the specificity of vaspin towards its protease targets and future work on the structural elucidation of vaspin in the Michaelis complex with these proteases is needed to fully understand the regulatory elements.

\subsection{Vaspin cofactors and non-protease interacting proteins}

Many serpins (and their respective target proteases) are able to bind to glycosaminoglycans (GAG) such as heparin, heparan sulfate or dermatan sulfate. Binding of these cofactors enables formation of ternary complexes, with the GAG molecule bridging serpin and protease (for a model see Figure 2), and induces Michaelis complex formation and thus accelerates protease inhibition [4].

Vaspin and KLK7 are both able to bind heparin [19] and KLK7 is furthermore moderately activated by heparin [39]. Vaspin has a high affinity for heparin ( $K_{D}$ of $\left.21 \mathrm{nM}\right)$ but it does not bind other GAGs such as dermatan sulfate or chondroitin sulfate. Inhibition of KLK7 by vaspin was accelerated 5-fold upon addition of heparin and a bell-shaped dose strongly suggested the template/bridging mechanism as underlying mechanism [40]. 
Most heparin-binding serpins interact with the GAG molecule via basic residues of the D-helix or $\mathrm{H}$-helix (Figure 2). While vaspin is a highly basic protein with a $\mathrm{pl}$ of 9.3 , there is only one large basic patch that is located on top of the central $\beta$-sheet A (Figure 2A, lower box). Mutations of basic residues K359 and R211 within this patch decreased heparin affinity $\left(K_{D} \sim 1 \mu \mathrm{M}\right)$ and reduced heparin-mediated acceleration of the inhibition reaction by $\sim 40 \%$ [40]. While the heparin-boost in KLK7 inhibition was moderate, cofactor binding at this site did not impede the serpin inhibition mechanism, i.e. insertion of the RCL into sheet $A$, and the SI in the presence of heparin remained unaltered [40]. Furthermore, the presence of heparin did not accelerate inhibition of KLK14 but impeded complex formation with vaspin [36].

To investigate whether heparin binding of vaspin has physiological relevance in addition to regulating serpin-protease interaction, vaspin expressing $\mathrm{HaCaT}$ cells [41] were used to analyze potential localization of vaspin in the extracellular matrix (ECM). Indeed, a high-salt wash or heparinase treatment of these cells increased vaspin levels measured in cell culture supernatants indicating that a significant amount of vaspin is localized in the ECM of cells [40]. High concentrations of vaspin were also found in the membrane fractions of liver tissue lysates of transgenic vaspin mice where it is co-localized with $\alpha$-2-macroglobulin, an important inhibitor of ECM degrading matrix metalloproteases [42].

Furthermore, with the $78 \mathrm{kDa}$ glucose-regulated protein (GRP78) a first non-protease interaction partner of vaspin was identified using tandem-affinity tag purification in HepG2 liver cells [42]. Interaction studies using chimeric vaspin-antitrypsin proteins (vaspin ${ }^{21-}$ 249/AT254-417 or AT $26-253 /$ vaspin $^{250-413}$ ) indicate that GRP78 is likely bound via the helical domains of the vaspin N-terminus and not via the RCL region [42]. The binding site of vaspin in the GRP78 molecule remains unclear. Binding was impaired by antibodies against N- and Cterminal domains of GRP78 as well as high concentrations of $\alpha$-2-macroglobulin [42], which interacts with N-terminal residues of GRP78 [43].

GRP78 is primarily known as an endoplasmic reticulum (ER) chaperone protein and important player in the unfolded protein response [44]. In recent years, GRP78 was also found on the cell surface of various tissues interacting with a variety of protein and peptide ligands (reviewed in [45]). Together with GRP78, likely functioning as a tissue-specific signaling hub, vaspin was found to be co-localized with the DnaJ-like protein MTJ1 in liver tissue [42] and with the voltage-dependent anion channel (VDAC) in human aortic endothelial cells [46]. It has been shown that the interaction of GRP78 with MTJ1 is necessary for translocation of GRP78 from the ER to the plasma membrane [47] where this complex also is a receptor for activated $\alpha$-2-macroglobulin [48] and mediates intracellular signaling via PI3-kinase, AKT and 
NFkB [45]. In endothelial cells, GRP78 together with VDAC serves as a receptor for kringel 5 (K5) $[49,50]$ to increase intracellular $\mathrm{Ca}^{2+}$ levels and apoptosis [51]. Binding of vaspin to GRP78 prevented apoptotic $\mathrm{K} 5$ effects while inducing anti-apoptotic intracellular signaling cascades via AKT kinase [46]. Vice versa, GRP78 binding was impaired and beneficial vaspin effects were decreased by $\mathrm{K} 5$. While the changes of intracellular $\mathrm{Ca}^{2+}$ levels are mediated by binding of $\mathrm{K} 5$ to VDAC [52], K5 is able to bind both, GRP78 and VDAC, and thus the binding site of GRP78 for vaspin remains unclear.

Investigation of liver tissue plasma membrane binding using ${ }^{125}$ /-labelled vaspin revealed a high-affinity $K_{D}$ of $22 \mathrm{nM}$, which is in the same range for heparin. Binding affinity to plasma membranes was not decreased by siRNA mediated GRP78 knock-down, though the maximum binding capacity was slightly reduced [42].

Together, these experiments indicate high affinity binding of vaspin to plasma membranes and the various intracellular signaling cascades activated by recombinant vaspin in in vitro cell models may in parts be mediated by binding of ECM GAGs or direct interaction with GRP78 and other molecules (Figure 3). Along these lines, GAG binding may direct and regulate vaspin activity as a serpin or as a ligand for cell surface molecules and non-heparin binding vaspin mutants as well as a better understanding of the interaction between vaspin and GRP78 will help to delineate these mechanisms.

\subsection{Glycosylation}

Human vaspin has three sites for $\mathrm{N}$-linked glycosylation with the consensus motif Asn-XSer/Thr (N221, N233 and N267) (Figure 2) and all of them are utilized when vaspin is expressed in eukaryotic expression systems [53]. For various serpins, these glycan modifications have been shown to be of great importance with respect to serpin secretion or plasma stability, serpin activity, inactivation via polymerization/aggregation and the interaction with GAGs. In contrast to other serpin glycoproteins, two of these glycosylation sites are located in close proximity to the RCL and near domains important for the extensive conformational changes underlying the serpin inhibition mechanism (Figure 2, upper box). Interestingly, rat and murine vaspin lack the two glycosylation sites near the $\mathrm{RCL}$, but have an additional predicted site near the bottom of helix C (N92) on the back side of the serpin molecule. The N267 glycosylation site is conserved.

For human vaspin, glycosylation does not alter anti-protease or more specifically anti-KLK7 activity and while the affinity for heparin is slightly reduced, heparin still accelerates the protease-inhibition reaction [53]. Glycosylation seems to be important for proper vaspin 
secretion. While intracellular expression of the glycan-null mutant in HEK cells was similar to wild type vaspin, secretion into cell supernatant was very low [53]. An important function of protein glycosylation is related to protein stability in the circulation. And while vaspin serum stability has not been thoroughly investigated, in vitro serum stability tests using fluorescently labelled vaspin derived from $E$. coli indicated high serum stability also for unglycosylated vaspin [53].

Importantly, consistent in vitro and in vivo findings have been reported in studies using unglycosylated (expressed in E. coli cells) or glycosylated (expressed in HEK293 cells) recombinant vaspin. It remains to be investigated whether physiologic functions of the glycoprotein vaspin are dependent or specifically affected by glycosylation.

\section{Physiology of Vaspin}

\subsection{Tissue expression of vaspin}

As mentioned above, Hida et al. identified vaspin mRNA as specifically expressed in visceral AT of the Otsuka Long-Evans Tokushima fatty (OLETF) rat and later reported the circulating form as a putative member of the serpin family [1,32]. In the OLETF rat, vaspin expression in visceral AT and vaspin serum concentration were highest when insulin resistance and obesity reached their peak and then decreased with the exacerbation of diabetes and concomitant body weight loss [32]. In Wistar rats, an animal model for diet-induced obesity (DIO), vaspin expression was observed in visceral as well as subcutaneous AT, but vaspin mRNA levels and protein expression were higher in the visceral depot and positively correlated with body weight [54]. Furthermore, increased vaspin expression was accompanied by elevated serum leptin levels [54].

In the first study investigating vaspin expression in human AT, vaspin mRNA expression was analyzed in 196 subjects, that comprised a wide range of BMI and insulin sensitivity, and included paired samples of visceral and subcutaneous AT [55]. Vaspin mRNA expression was only detectable in $23 \%$ of the visceral AT samples and in $15 \%$ of the subcutaneous AT samples, and an absence of vaspin expression was most frequent in healthy and lean subjects (BMI < 25). Multivariate regression analysis revealed increased body fat mass as the strongest predictor for visceral vaspin gene expression, while in subcutaneous AT, insulin sensitivity was the most powerful predictor for vaspin expression [55]. These data give further indications, that vaspin expression is induced by increased body weight, impaired glycemic control and metabolic syndrome and as such may represent a compensatory molecule in obesity, and related disorders such as inflammation and insulin resistance [30]. 
In a cohort of normal weight Korean women (mean BMI of 24), vaspin gene expression was found to be significantly greater in the adipocyte fraction than in the stromal vascular fraction of visceral (omental) adipose tissue [56]. Also, in the 40 subjects analyzed by computed tomography scan, vaspin expression was higher in the subcutaneous AT compared to the visceral. In contrast to the study of Lee et al. [56], a comparison of mRNA distribution of different proteins isolated from human omental AT of morbidly obese women (mean BMI of 46) undergoing bariatric surgery, demonstrated that vaspin is, in addition to preadipocytes and differentiated adipocytes, predominantly expressed in nonfat cells of the stromal vascular fraction [57]. In the OLEFT rat, Western and Northern Blot analysis of vaspin expression in subcutaneous and intra-abdominal AT depots clearly showed that vaspin mRNA as well as protein are expressed primarily in the adipocyte fraction and marginally in the SVF [32]. Vaspin is furthermore significantly expressed in brown adipose tissue (BAT) and brown adipocytes [58].

Importantly and in addition to ATs, multiple studies have demonstrated expression of vaspin in various other tissues, such as human skin [59,60], liver, pancreas [61], placenta [62], stomach, the cerebrospinal fluid and the hypothalamus of $o b / o b$ and C57BL/6N mice [63]. using different methods including qPCR, Western and Northern blots, ELISA and immunohisto chemistry. To obtain comparable expression data we have recently analyzed tissue-specific expression in mice and found highest expression levels of vaspin in skin, liver and brain compared to modest expression in ATs, spleen and low or non-detectable expression in bone marrow, muscle and kidney [58].

\subsection{Serum levels of vaspin}

Average vaspin serum levels in healthy subjects range from 0.18 to $1.55 \mathrm{ng} / \mathrm{ml}$ (meta-analysis in [64]) and a subpopulation of $7 \%$ of the Japanese and $1 \%$ of a European population exhibit vaspin levels of $>10 \mathrm{ng} / \mathrm{ml}$ and up to $>30 \mathrm{ng} / \mathrm{ml}$ [65]. Elevated vaspin serum levels in humans were shown to be associated with body-mass-index and insulin resistance $[66,65]$ and low vaspin serum concentrations represent a risk factor for the progression of type 2 diabetes (T2D) [67]. A number of studies found higher vaspin serum levels in obese $[68,69]$ and T2D patients $[70,65]$ but others could not confirm these results [66,71-73]. Due to the inconsistency of data, Feng et al. performed a large scale meta-analysis to evaluate the relationship between vaspin serum levels, obesity and T2D [64]. The meta-analysis addressing the relationship between vaspin serum levels and obesity enclosed six studies comprising 1833 participants and revealed a significantly increase of vaspin levels in obese patients with 
a mean difference of $0.51 \mathrm{ng} / \mathrm{ml}$ compared to non-obese controls. With respect to T2D, 1500 participants from 11 studies were included and also here vaspin serum levels were significantly higher in T2D patients with a mean difference of $0.36 \mathrm{ng} / \mathrm{ml}$ vaspin between groups. In conclusion, these analyses confirmed the presence of higher vaspin serum levels in obese and T2D patients [64].

With $24 \mathrm{~h}$ serum profiles, Jeong et al. addressed the influence of circadian rhythms on vaspin serum levels in healthy human subjects [72]. They observed a diurnal rhythm comprising a preprandial rise and postprandial fall of circulating vaspin levels with a nadir at midafternoon and a nocturnal peak reaching $250 \%$ of the minimum levels. This rhythm was reciprocal to insulin levels and following the post-prandial rise of insulin levels vaspin serum levels decreased to a minimum. To exclude meal-related from circadian influences, $24 \mathrm{~h}$ profiles were also analyzed in fasting patients as well as patients fed meals at unexpected times. In fasting patients, vaspin levels appeared to reach a maximum in the mid-afternoon and again unexpected meal ingestion caused suppression of vaspin serum concentrations subsequent to the postprandial insulin peak. Yet, the decrease of vaspin levels in the morning was still present in fasted patients, although delayed and with a lower amplitude. These data may indicate that vaspin levels are in part driven by a circadian clock [72].

A number of studies have investigated effects of weight loss, e.g. after bariatric surgery of lifestyle intervention, on vaspin serum levels. Golpaie et al. found decreased vaspin levels short-term (six weeks) after laparoscopic restrictive bariatric surgery in morbidly obese patients though serum vaspin levels did not correlate with metabolic parameters [74]. Handisurya et al. also observed decreased vaspin levels in morbidly obese patients 12 months after Roux-en-Y gastric bypass, but here changes in vaspin serum levels correlated positively with metabolic parameters such as insulin, C-peptide and HbA1c levels and HOMA-IR [75]. The correlation with HOMA-IR remained significant even after adjustment for surgery-induced BMI change. In contrast, Lu et al. observed stable vaspin levels in a subgroup of high-vaspin levels ( $>2.5 \mathrm{ng} / \mathrm{ml}$ at baseline) and a gradual increase in vaspin levels in a subgroup of lowvaspin levels $(<2.5 \mathrm{ng} / \mathrm{ml}$ at baseline) over 12 months after biliopancreaticdiversion/duodenal-switch bariatric surgery [76]. Overall, patients with high vaspin levels had the better metabolic profile throughout the study.

Results on vaspin regulation by weight-loss due to life-style intervention are more consistent and vaspin levels were decreased with weight-loss after short-term dietary intervention [77], after long-term weight loss intervention (independent from type of diet) [78]. Also, after 12 weeks of caloric restriction in combination with physical activity and orlistat administration 
vaspin levels were decreased, though only in the responder group with $>2 \%$ weight loss [79]. Obese patients diagnosed with polycystic ovary syndrome (PCOS) are at higher risk for impaired glucose tolerance, insulin resistance, dyslipidemia and T2D. Serum vaspin levels were significantly higher in PCOS patients compared to healthy subjects $(2.02 \mathrm{ng} / \mathrm{ml}$ versus 0.28 $\mathrm{ng} / \mathrm{ml} ; \mathrm{p}=0.048$ ) [80]. Interestingly, six months of dietary intervention in combination with metformin or orlistat treatment did not affect vaspin serum levels in both lean and obese patients with PCOS [80].

Studies investigating genetic variation identified a number of SNPS within and around the SERPINA12 gene that affect vaspin serum levels $[65,81,82]$. Thus, the rare functional vaspin variant rs61757459 results in a stop codon causing lower circulating vaspin concentrations [82] while the minor allele sequence $A$ of rs77060950 accounts for higher serum levels in $7 \%$ of the Japanese population [65]. With respect to genetic risk variants, a significant association of the SNP rs2236242 with T2D was identified in the German KORA study that was independent of obesity [83].

Clearance of vaspin and vaspin-protease complexes from the circulation remains unknown. Vaspin levels have been measured in patients on chronic hemodialysis and were similar to control patients indicating that vaspin is likely not cleared in the kidneys via renal excretion [71]. Many serpin-enzyme complexes of serpins such as $\alpha 1 \mathrm{AT}$, ATIII or HCII are rapidly cleared from the circulation via the low density lipoprotein receptor-related protein 1 (LRP1) expressed on hepatocytes in the liver [84,85]. It is unknown if vaspin-protease complexes can bind and be cleared via this receptor. In addition, vaspin interaction with GRP78 or other cell surface receptors in the liver and/or other tissues, as well as vaspin redistribution into the ECM may also contribute to vaspin clearance from the circulation. Furthermore, cell-surface or ECM localization of vaspin may contribute to the inconsistencies observed in many studies measuring circulating vaspin levels and also may disguise or complicate the finding of associations of circulating vaspin levels with aspects of the metabolic syndrome [86], although the many beneficial vaspin effects investigated on the cellular or tissue level seem to be indicative of those observations.

\subsection{Gene regulation by nutrients}

Body fat content and metabolism are mainly determined by total energy expenditure and energy intake, but the dietary macronutrient composition plays a crucial role in promoting related diseases such as the metabolic syndrome [87]. Dietary regulation of various adipokines 
has been investigated in many studies, demonstrating nutrition effects on adipokine expression and circulating levels (reviewed in [88]).

In order to address nutrient-specific effects on vaspin, we analyzed vaspin expression in mice fed matched low glycemic, high-fat or high-sugar diets [58]. Vaspin mRNA expression is unaffected in subcutaneous and visceral white AT depots, but was significantly enhanced in BAT and liver after both obesogenic diets. Interestingly, mice on the high-sugar diet gained significantly less body weight and body fat compared to the HFD, indicating an effect on vaspin expression independent of body weight. Counterintuitively, vaspin plasma levels were reduced after both HFD and HSD and thus, circulating vaspin does not seem to be a suitable predictor for vaspin tissue expression [58]. In line with these findings, vaspin serum levels were also decreased in a rat model of obesity-related T2D after 6 weeks of HFD [89].

In addition to the macronutrient itself, vaspin expression is regulated by the nutritional status. In rats, food restriction during gestation caused an increase in vaspin placenta expression [62] and fasting periods of $24 \mathrm{~h}$ and $48 \mathrm{~h}$ provoke a significant decrease in visceral AT vaspin mRNA levels [90]. Serum vaspin concentrations in humans also correlated positively with restraint, hunger and disinhibition in human eating behavior [91]. In accordance, undernourishment in girls with anorexia nervosa is accompanied with higher serum levels [92]. In contrast, in a cohort of 44 underweight children lower vaspin levels were observed compared to the healthy control group [93]. And also with respect to fasting effects on vaspin, also differing results were reported in which circulating vaspin serum levels were neither affected by short-term nor by chronic energy deprivation [94].

\subsection{Gene regulation by hormones/small molecules}

\subsubsection{Leptin}

This dissimilarity may result from potential fasting induced alterations in other hormone levels which in turn may influence vaspin expression. For instance, the adipokine leptin is well known to correlate with AT mass and fasting provokes a marked decrease in leptin plasma levels [95]. Along these lines, the fasting-induced decline in vaspin mRNA levels was partially reversible by leptin in rats, indicating an interrelationship between both adipokines [90]. However, neither acute nor chronic leptin treatment had an effect on vaspin serum levels in a human study [94].

Growth hormones Investigations in spontaneous dwarf rats, revealed the influence of growth hormones $(\mathrm{GH})$ on vaspin expression with blunted gonadal AT mRNA levels in GH-deficiency. 
Mentionable, these dwarf rats are characterized by lower body weight and insulin levels [90]. As discussed above, the model used in this analysis may itself influence data.

\subsubsection{Insulin / insulin sensitizers}

In the OLETF diabetic rat model, vaspin serum levels increased after treatment with insulin and the insulin sensitizing PPARy agonist pioglitazone [32]. Pioglitazone significantly induced vaspin protein expression and secretion in 3T3-L1 cells [75] and rosiglitazone in immortalized BAT cells [58]. PPAR $\alpha$ agonist fenofibrate increased vaspin mRNA expression in 3T3-L1 cells, visceral AT depots in rats, as well as serum levels in rats and humans [96]. Also, chronic treatment with the insulin-sensitizer metformin significantly increased vaspin expression in gAT of rats [90]. Intriguingly, data from human studies revealed controversial results. As such, metformin treatment significantly decreased vaspin serum levels in women with PCOS [97] and T2D patients [73]. Consistent results were reported in T2D patients receiving a rosiglitazone [70] or combined rosiglitazone and metformin therapy [98]. In patients with newly diagnosed T2D, short-term continuous subcutaneous insulin infusion significantly lowered vaspin serum levels associated with improved insulin sensitivity and changes in HOMA-IR [99]. In accordance, an acute insulin bolus caused a significant drop of vaspin serum concentration in healthy individuals [100]. This is particularly interesting in the context of the already mentioned meal-related diurnal variation of vaspin [72] and supports an insulindependent decrease in vaspin serum levels independent of nutritional influences.

\subsubsection{Thyroid hormones}

Regulation of vaspin by thyroid hormones has been investigated with controversial results. Vaspin mRNA expression in gAT of hypothyroid rats was increased while hyperthyroidism had the opposite effect [90]. A human study investigating the relationship of vaspin serum levels following weight loss by Roux-en-Y gastric bypass (RYGB) surgery reported a positive correlation between decreased thyroid-stimulating hormone (TSH) and vaspin serum levels [75]. In contrast, a study in overt and subclinical hypothyroid patients found no significant association between vaspin levels and thyroid hormone status. Vaspin levels were neither changed by hypothyroidism nor after treatment with the thyroxine analog levothyroxine [101]. Together, there is no clear evidence for a regulation of vaspin by TSH (or vice versa) or whether indirect mechanisms are involved.

\subsubsection{Sex steroids}


Analyzing gender-specific differences the majority of studies showed higher vaspin levels in females $[66,71,99,90,102]$ while others did not [59]. Interestingly, vaspin serum levels were significantly enhanced in women using oral contraceptives [102] and also combined therapies using metformin and oestrogen/progestogen enhanced vaspin serum levels in non-obese women with hyperinsulinaemic androgen excess [103]. Elevated serum levels and omental AT expression was also observed in obese women with PCOS and dehydroepiandrosterone sulfate (DHEA-S) significantly induced vaspin protein expression and secretion in omental adipose tissue explants [97]. In children, circulating vaspin levels were higher in girls and increased with age and pubertal stage but did not correlate with sex-steroids [61]. In accordance, no differences in serum levels were found between pre-and postmenopausal women [75] and mRNA expression in gonadal white AT was neither changed in pregnant nor in gonadoectomized rats [90]. Hence, more research is necessary to clarify the underlying mechanisms leading to the observed sexual dimorphism in vaspin levels.

Recently, multiple studies investigated the relationship between vaspin and PCOS, a common endocrine disorder affecting women in the reproductive age. Also here, some studies reported enhanced vaspin serum levels in PCOS patients $[97,80,104]$ while others found no association $[105,106]$. It is important to note, that PCOS is often associated with insulin resistance, obesity or T2D [107], i.e. parameters with direct effects on vaspin levels and the variability in the data may arise from inhomogeneous study cohorts and also applied diagnostic criteria [108].

\section{Multifaceted and tissue-specific functions of vaspin - in vivo and in vitro data}

3.1. Vaspin and obesity related insulin-resistance

In their pioneering study following the identification of the vaspin gene, Hida et al. demonstrated the beneficial effect of vaspin on insulin sensitivity and glycemic control [32]. Administration of recombinant vaspin improved glucose tolerance and insulin sensitivity in diet-induced obese (DIO) and insulin resistant mice. In addition, vaspin application ameliorated expression of marker genes, such as leptin, resistin, glucose transporter-4 and Tnf- $\alpha$, reflecting amendment of diet-induced insulin resistance in AT. These findings lead to the hypothesis of vaspin acting as an insulin sensitizer also with anti-inflammatory effects counteracting obesity-related insulin resistance in AT. To further support this hypothesis, Nakatsuka et al. generated vaspin transgenic (tg) and knock-out (KO) mice to dissect the physiologic roles of vaspin in gain and loss of function animals [42]. Vaspin expression was specifically induced in AT using the aP2 promotor (vaspin_tg), while the KO was a general knock-out (vaspin_KO). In line with the previous findings, transgenic overexpression of vaspin 
in adipose tissue of mice protected animals from HFD-induced AT inflammation and insulin resistance while KO animals displayed deteriorated metabolic functions accompanied by adipocyte hypertrophy and AT inflammation under HFD. Unexpectedly, the most striking effects of increased vaspin expression after HFD were observed in the liver. Vaspin_tg mice were protected from hepatic steatosis, with less hepatic lipid incorporation and triglyceride content and showed improved insulin signaling and reduced mRNA expression of gluconeogenic and lipogenic genes. These effects were at least in part mediated by the interaction of vaspin with cell surface protein GRP78 (see above and Figure 3) and reduction of GRP78 expression reduced glucose tolerance in HFD-fed vaspin_tg mice [42].

With the identification of KLK7 as a target protease of vaspin, we investigated whether known beneficial vaspin effects on glucose metabolism in obesity may be related to inhibition of KLK7 or other proteases [17]. Importantly, inactive vaspin mutants (A369P, see above) failed to improve glucose tolerance in HFD insulin resistant mice, suggesting that this effect is at least in part based on protease inhibition by vaspin. And while hyperinsulinemic-euglycemic clamps did not show increased insulin sensitivity in vaspin treated mice, we observed increased insulin levels upon a glucose challenge in vaspin treated mice, as well as increased insulin levels in glucose stimulated and vaspin treated isolated pancreatic islets, both without increased Cpeptide levels. These data indicated that improved glucose metabolism was also independent of insulin secretion. Interestingly, vaspin and KLK7 are co-expressed in pancreatic islets, and insulin is a substrate of KLK7. Thus, the compensatory action of vaspin in obesity-related insulin resistance is likely mediated by inhibition of KLK7 and potentially further proteases, thereby regulating insulin degradation and increasing insulin half-life (Figure 3) [17].

Following up, we generated an AT-specific KIk7 KO mice to investigate the role of KLK7 in AT, obesity and insulin resistance. AT-KIk7-KO mice gained less weight under HFD with expansion of predominantly subcutaneous fat and improved insulin sensitivity [109]. In agreement with improved insulin sensitivity, HFD-induced local (in AT) and systemic inflammation was significantly reduced. As a consequence of reduced expression of proinflammatory cytokines, such as interleukine (IL)-1 $\beta$, IL-6 and monocyte chemoattractant protein-1 (Mcp-1), an increased number of AT macrophages of the anti-inflammatory M2 type was present in AT of AT-KIk7-KO mice. Furthermore, indirect calorimetry revealed that KLK7 deficient HFD mice exhibit increased energy expenditure and food intake, which may be due to lower circulating leptin serum levels [109]. Yet, further research is necessary to identify the physiological substrates of KLK7 in AT which contribute to the improvement of inflammation and insulin sensitivity. Many of the inflammatory cytokine candidates have already been identified as 
substrates of KLK7, such as IL-1 $\beta$, chemerin, midkine or MMP-9 and may be relevant in the process. Together, these data demonstrate a previously unknown role of KLK7 in obesityrelated inflammation of AT and insulin resistance (Figure 4) and suggest specific small compound KLK7 inhibitors as promising therapeutic molecules to combat obesity-related metabolic diseases.

\subsection{Vaspin in adipose tissue}

In the AT of HFD-induced obese and insulin resistant mice, administration of intraperitoneal (i.p.) vaspin resulted in an improved expression profile of genes associated with AT inflammation and insulin resistance such as leptin, resistin, Tnf- $\alpha$ and glucose transporter-4 [32]. Transgenic overexpression of vaspin in AT of mice resulted in ameliorated local AT inflammatory gene expression and also in reduced systemic IL-6 levels both under chow and HFD diet [42]. Also, HFD-induced adipocyte hypertrophy was lower in vaspin tg mice, while vaspin KO increased adipocyte diameters also under chow diet [42]. This lead to the hypothesis that vaspin may act as a compensatory molecule against AT inflammation and insulin resistance in obesity. A few studies have since addressed auto- or paracrine functions of vaspin on adipocytes.

Results of vaspin effects on adipogenesis and lipid incorporation into mature adipocytes are controversial. Using 3T3-L1 adipocytes, Liu et al. reported high vaspin concentrations (up to $200 \mathrm{ng} / \mathrm{ml}$ ) to promote lipid accumulation and higher mRNA as well as protein expression of adipocyte-specific marker genes like Ppary and Fabp-4 in a dose dependent manner [110]. However, we did not observe effects of vaspin on adipogenesis and lipid incorporation using 3T3-L1 cells with exogenous vaspin treatment as well as stably overexpressing Vaspin_3T3-L1 cells [111].

Chronic treatment with vaspin during differentiation of 3T3-L1 cells decreased the mRNA expression of the pro-inflammatory cytokine $I I-6$ and increased Glut-4 expression [110]. Furthermore, vaspin overexpression in 3T3-L1 cells significantly reduced inflammatory cytokine action in these cells [111]. IL-1ß-induced mRNA expression of Mcp-1 and II-6 and secretion of IL-6 and TNF- $\alpha$ was significantly diminished in the vaspin-expressing adipocytes. These effects were likely mediated by blunted intracellular NFKB-signaling due to decreased phosphorylation of the upstream kinase IKK $\alpha / \beta$ and the NFKB-inhibitor IKB following IL-1 $\beta$ treatment in vaspin expressing adipocytes [111].

In addition, we found significantly increased AKT phosphorylation after insulin-stimulation of vaspin overexpressing differentiated 3T3-L1 adipocytes [111]. AKT phosphorylation was not 
different under basal conditions in these cells, though Liu et al. observed a slight increase in basal AKT phosphorylation in premature 3T3-L1 cells after short term vaspin treatment [110]. Taken together, vaspin seems to have direct anti-inflammatory effects on adipocytes which may contribute to improved insulin sensitivity and glucose uptake (Figure 4). However, the mechanism underlying the induction of intracellular signaling cascades, whether protease mediated or via direct interaction with cell surface receptors or both, remain unclear.

\subsection{Vaspin in brown adipose tissue and thermogenesis}

Within the last years, brown adipose tissue and especially its recruitment and activation came back into the focus as a new therapeutic target to combat obesity and ameliorate metabolic diseases (reviewed in $[112,113]$ ). The dominant regulator of BAT activation is cold-sensing by the central nervous system, initiating a sympathetic outflow that stimulates the release of noradrenaline (NA). NA than agonizes adrenergic receptors on brown adipocytes and triggers the activation of signaling cascades resulting in expression of thermogenic genes. Besides cold, activation of BAT and non-shivering thermogenesis was also shown to be achieved by nutritional factors [114] and a plethora of physiological and pharmacological agents (reviewed in $[115,116])$.

In this context, a microarray study comparing intrinsic differences in cold induced gene expression of murine white and brown adipose depots disclosed vaspin under the top upregulated genes after cold exposure in BAT [117]. In our studies, we could confirm that vaspin mRNA and protein expression is specifically enhanced in activated BAT of mice subjected to either cold or diabetogenic diets [58]. In accordance, vaspin mRNA expression was significantly higher in immortalized brown compared to white adipocyte cell lines and further increased during adipocyte differentiation. Interestingly, $\beta$-adrenergic stimulation by $N A$ and by the $\beta(3)$-adrenergic agonist CL316,243 failed to induce vaspin expression in vitro. Methylation analyses within the vaspin promoter further identified acute epigenetic changes in BAT upon cold exposure that may contribute to elevated vaspin mRNA expression. Notably, vaspin plasma levels where decreased upon BAT activation [58]. In light of BAT thermogenesis and AT browning as current targets to tackle obesity and diabetes, the dynamic and BATspecific regulation of vaspin is a promising starting point to further investigate functional relevance of vaspin in BAT as well as in BAT function. 


\subsection{Vaspin in vascular cells}

Multiple lines of evidence over the last years have established the role of vaspin in improving the function of endothelial and smooth muscle cells under hyperlipidemic, hyperglycemic and proinflammatory conditions associated with obesity and insulin resistance by counteracting vascular inflammation and oxidative stress.

Chronic inflammation in obesity results in AT dysfunction and the secretion of proinflammatory adipokines contributes to endothelial dysfunction. Although a first study obtained negative results, various subsequent studies revealed potent anti-inflammatory action of vaspin in endothelial cells. Initially, vaspin was shown to not inhibit TNF- $\alpha$ triggered inflammatory signaling pathways in human umbilical vein endothelial cells (HUVECS) [118]. Both, acute TNF- $\alpha$-induced activation of intracellular c-Jun N-terminal kinase (JNK), mitogenactivated protein kinase (p38), and NF-KB, and long-term TNF- $\alpha$ mediated changes in mRNA expression of cellular adhesion molecules as well as MCP-1 were unaffected by vaspin [118]. In other vascular cells though, it was clearly demonstrated that vaspin inhibited TNF- $\alpha$ induced IKB $\alpha$ degradation and subsequent NF-KB activation in human aortic endothelial cells (HAECs) as well as in vascular smooth muscle cells (VSMC) $[119,120]$. Luciferase reporter gene assays in human endothelial EA.hy926 cells showed that vaspin decreased TNF- $\alpha$ and IL-1 $\beta$ induced NF-KB transcriptional activity, resulting in diminished expression of pro-inflammatory cytokines such as IL-1 and IL-6 [121]. Inflammatory cytokines TNF $\alpha$ and IL-1 $\beta$ induce expression of cellular adhesion molecules ICAM and VCAM, which in turn promote monocyte and platelet activation, adhesion and migration. Multiple studies demonstrated that vaspin prevented TNF- $\alpha$-induced expression of intercellular adhesion molecule (ICAM), vascular cell adhesion molecule (VCAM) and E-selectin as well as MCP-1 expression which resulted in reduced monocyte adhesion [119-121]. siRNA-mediated knock down of AMP-activated protein kinase (AMPK) expression attenuated the effect of vaspin on cytokine-induced NF-KB activation and indicated the activation of AMPK as an signaling pathway [120]. Also in pulmonary artery SMC vaspin inhibited IL-1 $\beta$-induced activation of matrix metalloproteinase (MMP-2) and generation of reactive oxygen species (ROS) [122].

Dyslipidemia is a major contributor to insulin resistance and also endothelial dysfunction. Vaspin ameliorated the apoptotic effect of increased free fatty acids (FFA) in insulinstimulated HAECS [123]. FFA such as linoleic acid (LA) decreased insulin-sensitivity and induced apoptosis and caspase 3 activity in vascular endothelial cells. Both effects were prevented by vaspin treatment. Furthermore, pretreatment with the PI3-inhibitor 
Wortmannin indicated that vaspin prevents FFA-induced cell death via upregulation of the PI3-Akt signaling cascade (Jung 2011).

Under hyperglycemic conditions vaspin was shown to reduced hyperglycemia (HG)-induced vascular smooth muscle cell proliferation and chemokinesis [124]. These effects were mediated by inhibition of HG-induced activation and phosphorylation of intracellular signaling pathways, such as p38-MAPK, the insulin receptor signaling axis and NF-KB signaling, leading to decreased production of ROS [124]. The effect of vaspin on insulin signaling seems to be different in smooth muscle cells compared to endothelial cells, though these alterations may also be due to the different glucose stimulation conditions (chronic vs. acute).

In T2D patients, pathological elevated serum levels of methylglyoxal (MGO), a highly reactive dicarbonyl metabolite, contribute to the formation of advanced glycation end products (AEG). Consequently, AEGs are partly responsible for diabetes associated microvascular events, impaired insulin signaling and hinder host self-defense mechanism against vascular inflammation $[125,126]$. Treatment of cultured human umbilical vein endothelial cells (HUVECS) with MGO resulted in caspase-dependent apoptosis, while pretreatment with vaspin depleted MGO-induced cell death by preventing the generation of MGO-induced ROS, activation of NADPH oxidase (NOX) and subsequent activation of caspase-3 [127]. Also, endothelial proliferation after vascular injury was ameliorated by application of vaspin or vaspin_adenovirus in streptozotocin-induced diabetic Wistar-Kyoto rats as well as in arteries of vaspin transgenic mice [46]. Vaspin treatment induced proliferation and reduced apoptosis in isolated HAEC, where the interaction with GRP78 mediated vaspin-induced activation of AKT signaling [46]. Also, sh-RNAs targeting GRP78 and VDAC inhibited the vaspin-induced AKT activation and downstream anti-apoptotic signaling. Thus, the authors suggested the vaspinGRP78-VDAC cell surface complex as a possible key signaling hub mediating the vaspin signal into the cell with subsequent anti-apoptotic, anti-inflammatory and thus cardio-protective effects [46].

Nitric oxide (NO), generated by endothelial NO synthase (eNOS), plays the central role in vasodilatation and reduced NO-bioavailability and excessive ROS generation mainly contribute to endothelial dysfunction in obesity (reviewed in [128,129]. As mentioned above, vaspin has been shown to reduce ROS generation induced by hyperglycemia and increased MGO/AGE, conditions typical for T2D. Also, vaspin attenuated platelet-derived growth factorBB (PDGF-BB)-induced migration of VSMC and this effect was mediated by inhibition of intracellular ROS generation, which blunted phosphorylation of p38-MAPK and HSP27 signaling [130]. In addition, vaspin has been shown to enhance bioavailability of NO in 
endothelial cells. Vaspin increased both eNOS expression and activation via STAT3 signaling and, in parallel, induction of dimethylarginine dimethylaminohydrolase (DDAH) II expression, which is the enzyme responsible for the degradation of the endogenous inhibitor of eNOS in asymmetric dimethyl-L-arginine (ADMA) [131]. Vaspin counteracted hyperglycemia induced eNOS inhibition in endothelial progenitor cells by inducing eNOS expression and activity via activation of the PI3-AKT pathway [132]. Vasodilation by NO is induced by increased intracellular $\mathrm{Ca}^{2+}$ levels or by acetylcholine receptor agonists like acetylcholine (ACh). Vaspin increased ACh-induced vaso-relaxation and ACh-induced eNOS phosphorylation in rat mesenteric arteries, while it had no effect on relaxation induced by other NO-inducing vasodilators such as histamine or carbachol and it also did not affect vasocontraction [133]. Interestingly, these effects were induced by vaspin mediated inhibition of ACh esterase (AChE) activity by $\sim 25 \%$. With respect to the catalytic mechanism of AChE to convert ACh to choline and acetic acid, which has similarities to serine proteinases, it was speculated that vaspin may directly inhibit AChE via the serpin mechanism [133].

These in vitro findings were confirmed in spontaneous hypertensive rats (SHR) in vivo. Rats receiving long-term intraperitoneal vaspin application over 4 weeks maintained significantly lower systolic blood pressure (SBP). In isolated artery from SHR rats, vaspin did not alter vessel reactivity, but reduced arterial wall hypertrophy and ameliorated inflammatory TNF-a expression and ROS generation [134]. In accordance, in an animal model of monocrotaline (MCT)-induced pulmonary arterial hypertension (PAH), vaspin ameliorated PA pressure. In isolated PA, vaspin averted MCT-induced fibrosis but not hypertrophy of the vessel wall and reduced MCT-induced ROS generation and MMP-2 activation in lung tissues [122].

In apolipoprotein E deficient mice, a mouse model spontaneously developing atherosclerotic lesions, vaspin_lentivirus application inhibited the progression of atherosclerotic plaque development [135]. Vaspin_lentvirus application did not cause major alterations in the blood lipid profile, but reduced ER-stress in macrophages of ApoE-deficient mice [135].

Dysfunction of the endothelial barrier of pulmonary endothelial cells entails excessive leakage of fluid in the acute respiratory distress syndrome (ARDS). Using a lipopolysaccharide (LPS)induced mouse model of ARDS, it was shown that vaspin dampened pulmonary inflammation and improved endothelial barrier function accompanied by activation of the AKT/GSK3 pathway [136]. In isolated human pulmonary endothelial cells, vaspin treatment blunted LPSinduced generation of ROS, ameliorated inflammation and reduced apoptosis with contributions via the AKT signaling [136]. 
Together, these data clearly established beneficial effects of vaspin counteracting vascular inflammation, excessive ROS production and NO bioavailability (Figure 4) and thus demonstrate its potential to preserve vascular function, lower blood pressure and the endothelial barrier.

\subsection{Vaspin in the brain - central action of vaspin}

In addition to their direct effects on peripheral tissues, many prominent hormones and adipokines such as insulin, leptin and adiponectin regulate energy expenditure and glucose homeostasis through central actions in the brain (reviewed in $[137,138]$ ). Based on the detection of vaspin in cerebrospinal fluid, Klöting et al. first reported central effects of vaspin [63]. Intracerebroventricular (icv) administration of vaspin acutely decreased food intake and lowered blood glucose levels in healthy C57BL/6N and obese $d b / d b$ mice. Interestingly, in obese and insulin resistant $d b / d b$ mice glucose levels remained lower for six days after a single icv injection of vaspin [63]. Also, intrahypothalamic injection of vaspin in healthy and lean Wistar rats reduced food intake in $24 \mathrm{~h}$ after injection [139]. In the hypothalamus, vaspin injection reduced expression of orexigenic neuropeptide $Y$ accompanied by a parallel increase in anorexigenic proopiomelanocortin expression $24 \mathrm{~h}$ after injection [139]. Expression of AgRP, orexin-A, CART and $\mathrm{CRH}$ remained unchanged.

Luo et al. focused in detail on the central vaspin effects on glucose homeostasis after icv application in rats fed a chow or HFD [140]. Again and under both diet regimes, food intake was acutely decreased for $24 \mathrm{~h}$ after a single vaspin bolus. In the HFD-fed rats, icv vaspin also increased the metabolic rate and elevated hypothalamic Fos expression. Neuronal Fos is expressed following voltage gated calcium influx and rapidly and transiently induced by neuronal excitation [141]. Continuous icv infusion of vaspin during hyperinsulinemiceuglycemic clamps increased glucose infusion rates necessary to maintain euglycemia, but only in the HFD animals. The increased insulin sensitivity was based on reduced hepatic glucose production, with the reduction of gluconeogenesis and glycogenolysis contributing $60 \%$ and $40 \%$, respectively. Together, the suppression of hepatic glucose flux indicated improved hepatic insulin sensitivity and was accompanied by increased phosphorylation and activation of the insulin signaling cascade in HFD fed rats after icv vaspin [140]. Signaling via the hepatic branch of the vagus nerve was investigated as an underlying mechanism of these regulatory effects. Indeed, hepatic vagotomy prevented central vaspin effects in clamp experiments and demonstrated that hepatic innervation is required for the glucose lowering effects of central vaspin [140]. In the brain, pharmacologic inhibition of NMDA receptors in 
dorsal vagal complex also prevented icv vaspin effects on glucose infusion rates and hepatic glucose production, indicating that vaspin signaling is transmitted by NMDA receptor expressing neurons in the DVC to nucleus of the solitary tract and subsequently to the liver via the hepatic branch of the vagus nerve [140]. The finding of a neural signaling axis from the brain to the liver mediating central vaspin effects on energy balance, glucose homeostasis and insulin signaling (Figure 5) raises many new questions. It is unknown whether these effects are mediated by vaspin expressed in peripheral tissues or by specific neurons in the brain. Additionally, it remains unclear, whether these effects are direct effects of vaspin acting on specific neurons binding to cell surface receptors such as GPR78 (Figure 3). Also indirect mechanisms via the regulation of protease activities and their substrates (e.g. KLK7 and insulin) could contribute as well, as central insulin is known to decrease food intake and to increase energy expenditure via POMC neurons and the DVC [142,143].

\subsection{Vaspin in bone}

There is a wealth of experimental evidence for the modulation of metabolic bone function by adipokines (reviewed in [144]). In patients with rheumatoid arthritis (RA), a chronic inflammatory joint disease, vaspin serum levels were increased [145] and vaspin levels were also elevated in synovial fluid of RA, but not in osteoarthritis (OA) patients [146]. In line, a follow-up study investigating the risk of developing RA in auto-antibody positive patients found a significant association between vaspin serum levels and the pathogenesis of RA, even after adjustment for overweight [147]. Studies evaluating the relationship between vaspin and bone mineral density (BMD) obtained diverging results. In inflammatory disease states, no correlation was found between vaspin and BMD in patients with multiple sclerosis [148] or inflammatory bowel disease [149]. In contrast, a recent study in post-menopausal women (22\% of the cohort had osteoporosis) revealed a significant positive association between vaspin serum levels and BMD in femoral neck (FN) and total hip after adjustment for age, body composition and various other parameters [150].

The role of vaspin in bone metabolism has been investigated in in vitro studies demonstrating bilateral effects on both, bone- forming osteoblasts and bone-resorbing osteoclasts. In vitro, vaspin protected human osteoblasts from apoptosis in a dose-dependent manner [151]. On the cellular level, vaspin treatment resulted in enhanced protein expression of anti-apoptotic $\mathrm{Bcl}-2$ and attenuated pro-apoptotic Bax expression via activation of the MAPK/ERK signaling pathway. Interestingly, vaspin treatment had no effects on PI3-K/AKT, p38 or JNK pathways in human osteoblasts [151]. On the other hand, recent studies in the murine pre-osteoblast 
MC3T3-E1 cell line revealed an inhibitory or at least a modulating effect of vaspin on osteogenic differentiation [152]. In particular, vaspin dose-dependently attenuated osteogenic differentiation by activation of the PI3K-signaling pathway leading to elevated miR$34 \mathrm{c}$ levels which reversely modulate the activation of PI3K-Akt signaling by targeting the tyrosine kinase receptor c-met. Thus, vaspin seems to participate in a regulatory PI3KAkt/miR-34c loop involved in osteogenic differentiation [152]. Along these lines, RANKLinduced osteoclastogenesis of RAW264.7 and bone marrow-derived cells was prevented by vaspin treatment through inhibition of the master regulator of osteoclastogenesis, nuclear factor of activated T cells c1 (NFATc1) [153]. In RAW264.7 cells, vaspin inhibited RANKLinduced expression of bone resorption-related proteases cathepsin K and MMP-9 [153]. While the molecular mechanisms remain to be fully understood, these data indicate a dynamic regulation of bone metabolism by vaspin with induction of bone-formation and suppression of bone erosion (Figure 5). This dual action profile suggests therapeutic value for the treatment of osteoporosis or rheumatoid arthritis.

\subsection{Vaspin in skin}

Psoriasis is a chronic inflammatory skin disease and commonly associated with other pathological conditions such as obesity and T2D [154]. In 2012, Saalbach et al. reported first evidence linking vaspin expression in skin with psoriatic skin disease [59]. They identified keratinocytes as the major source of skin-derived vaspin and compared psoriatic skin biopsies of lesional and non-lesional areas. Interestingly, in non-lesional skin, vaspin expression was detectable across all epidermal layers, while it was decreased in lesional psoriatic skin [59]. However, an association of vaspin serum levels and psoriasis is still discussed controversial. While Saalbach et al. did not observe differences in vaspin levels in healthy and psoriatic patients [59], other studies observed vaspin serum levels significantly decreased in patients with psoriasis [155] or systemic sclerosis with digital ulcers [156]. After the identification of KLK7 as a protease target of vaspin, subsequent studies revealed distinct co-expression of vaspin with its target protease KLK7 in healthy skin as well as non-lesional skin of psoriasis patients while co-localization and expression was decreased in lesional psoriatic skin sections [157]. KLK7 is a chymotryptic serine protease that was initially identified in skin, where it is involved in the skin desquamation process [33] and overexpression and aberrant activity of KLK7 is related to pathogenesis of inflammatory skin diseases such as psoriasis [34] and acne rosacea [35]. This lead to the hypothesis that vaspin may be involved in the fine-tuned balance of proteases involved in the regulation of inflammatory processes in the skin. 
Recently, Saalbach et al. also investigated the role of vaspin in dysregulated immune cell and keratinocyte interaction leading to chronic inflammatory skin diseases [41]. Vaspin expression was highly dynamic during the differentiation stages of the epidermis and down-regulation of vaspin expression in keratinocytes lead to the activation of an altered gene cluster, characterized by reduced expression of differentiation-associated genes and an increased expression of proinflammatory cytokines. Moreover, vaspin expression in keratinocytes modulated the crosstalk between keratinocytes and immune cells in co-culture, thereby affecting the cytokine secretion profile of the inflammatory cells. These data suggest a protective role of vaspin in inflammatory skin diseases which was supported by in vivo experiments, in which vaspin application prevented myeloid cell infiltration in a psoriasis-like mouse model [41].

\section{Concluding remarks}

In conclusion, the recent years have established vaspin as a multifaceted molecule with beneficial functions in various tissues, whether in auto- or endocrine ways or signaling from the brain to target tissues such as the liver (Figure 6). We have discussed the diverse effects of vaspin in vivo and in vitro, and the data suggests that the main principle of vaspin function is to protect cells and tissues from inflammation under proinflammatory conditions found in obesity. And this protective, compensating or counteracting function, whether in adipocytes, vascular, skin or bone cells, seems to be executed via both, the regulation of protease activity and the interaction with cell surface receptors such as GRP78. Yet, the exact underlying mechanisms of signal transduction for many of the reported effects of vaspin remain to be elucidated and more research is needed to dissect the contributing pathways. Very likely, further receptors and target proteases are to be identified. A better understanding of these divers signaling pathways utilized by vaspin will help to employ this molecule, agonists of its receptors or inhibitors of its target protease(s) for new pharmacologic strategies to treat obesity associated inflammation, insulin resistance and atherosclerosis.

Acknowledgements: Dr. Rene Meier and Sabina Kanton are kindly acknowledged for the homology modelling of the vaspin RCL. Our work is supported by the Deutsche Forschungsgemeinschaft SFB1052 "Obesity Mechanisms" (C07).

Author contributions: JW, KZ and JP wrote the manuscript. JW and JP created figures. JTH critically edited the manuscript. 
Conflicts of Interest: No conflicts of interest are declared by the authors.

Ethical Approval: This article does not contain any studies with human participants or animals performed by any of the authors. 


\section{References}

1. Hida K, Wada J, Zhang H, Hiragushi K, Tsuchiyama Y, Shikata K, Makino H (2000) Identification of genes specifically expressed in the accumulated visceral adipose tissue of OLETF rats. J Lipid Res 41 (10):1615-1622

2. Gettins PG (2002) Serpin structure, mechanism, and function. Chem Rev 102 (12):4751-4804. doi:cr010170+ [pii]

3. Silverman GA, Bird PI, Carrell RW, Church FC, Coughlin PB, Gettins PG, Irving JA, Lomas DA, Luke CJ, Moyer RW, Pemberton PA, Remold-O'Donnell E, Salvesen GS, Travis J, Whisstock JC (2001) The serpins are an expanding superfamily of structurally similar but functionally diverse proteins. Evolution, mechanism of inhibition, novel functions, and a revised nomenclature. J Biol Chem 276 (36):3329333296. doi:10.1074/jbc.R100016200

R100016200 [pii]

4. Gettins PG, Olson ST (2009) Exosite determinants of serpin specificity. J Biol Chem 284 (31):2044120445. doi:10.1074/jbc.R800064200

\section{R800064200 [pii]}

5. Engh R, Lobermann H, Schneider M, Wiegand G, Huber R, Laurell CB (1989) The S variant of human alpha 1-antitrypsin, structure and implications for function and metabolism. Protein Eng 2 (6):407-415 6. Lawrence DA, Olson ST, Muhammad S, Day DE, Kvassman JO, Ginsburg D, Shore JD (2000) Partitioning of serpin-proteinase reactions between stable inhibition and substrate cleavage is regulated by the rate of serpin reactive center loop insertion into beta-sheet $A$. Journal of Biological Chemistry 275 (8):5839-5844. doi:DOI 10.1074/jbc.275.8.5839

7. Stratikos E, Gettins PG (1999) Formation of the covalent serpin-proteinase complex involves translocation of the proteinase by more than $70 \mathrm{~A}$ and full insertion of the reactive center loop into beta-sheet A. Proc Natl Acad Sci U S A 96 (9):4808-4813

8. Huntington JA, Read RJ, Carrell RW (2000) Structure of a serpin-protease complex shows inhibition by deformation. Nature 407 (6806):923-926. doi:10.1038/35038119

9. Dementiev A, Dobo J, Gettins PG (2006) Active site distortion is sufficient for proteinase inhibition by serpins: structure of the covalent complex of alpha1-proteinase inhibitor with porcine pancreatic elastase. J Biol Chem 281 (6):3452-3457. doi:M510564200 [pii]

\subsection{4/jbc.M510564200}

10. Kaslik G, Patthy A, Balint M, Graf L (1995) Trypsin complexed with alpha 1-proteinase inhibitor has an increased structural flexibility. FEBS Lett 370 (3):179-183. doi:0014-5793(95)00816-R [pii]

11. Stavridi ES, O'Malley K, Lukacs CM, Moore WT, Lambris JD, Christianson DW, Rubin H, Cooperman BS (1996) Structural change in alpha-chymotrypsin induced by complexation with alpha 1antichymotrypsin as seen by enhanced sensitivity to proteolysis. Biochemistry 35 (33):10608-10615. doi:10.1021/bi9605806

\section{bi9605806 [pii]}

12. Perlmutter DH, Glover GI, Rivetna M, Schasteen CS, Fallon RJ (1990) Identification of a serpinenzyme complex receptor on human hepatoma cells and human monocytes. Proc Natl Acad Sci U S A 87 (10):3753-3757

13. Joslin G, Griffin GL, August AM, Adams S, Fallon RJ, Senior RM, Perlmutter DH (1992) The serpinenzyme complex (SEC) receptor mediates the neutrophil chemotactic effect of alpha-1 antitrypsinelastase complexes and amyloid-beta peptide. J Clin Invest 90 (3):1150-1154. doi:10.1172/JCI115934 14. Huntington JA (2006) Shape-shifting serpins--advantages of a mobile mechanism. Trends Biochem Sci 31 (8):427-435. doi:S0968-0004(06)00167-8 [pii]

\subsection{6/j.tibs.2006.06.005}

15. Gils A, Knockaert I, Declerck PJ (1996) Substrate behavior of plasminogen activator inhibitor-1 is not associated with a lack of insertion of the reactive site loop. Biochemistry 35 (23):7474-7481. doi:10.1021/bi960079d

bi960079d [pii] 
16. Carrell RW, Stein PE (1996) The biostructural pathology of the serpins: critical function of sheet opening mechanism. Biol Chem Hoppe Seyler 377 (1):1-17

17. Heiker JT, Kloting N, Kovacs P, Kuettner EB, Strater N, Schultz S, Kern M, Stumvoll M, Bluher M, Beck-Sickinger AG (2013) Vaspin inhibits kallikrein 7 by serpin mechanism. Cell Mol Life Sci 70 (14):2569-2583. doi:10.1007/s00018-013-1258-8

18. Pippel J, Kuettner EB, Ulbricht D, Daberger J, Schultz S, Heiker JT, Strater N (2016) Crystal structure of cleaved vaspin (serpinA12). Biol Chem 397 (2):111-123. doi:10.1515/hsz-2015-0229

/j/bchm.2016.397.issue-2/hsz-2015-0229/hsz-2015-0229.xml [pii]

/j/bchm.just-accepted/hsz-2015-0229/hsz-2015-0229.xml [pii]

19. Ulbricht D, Pippel J, Schultz S, Meier R, Strater N, Heiker JT (2015) A unique serpin P1' glutamate and a conserved beta-sheet $C$ arginine are key residues for activity, protease recognition and stability of serpinA12 (vaspin). Biochem J 470 (3):357-367. doi:10.1042/BJ20150643

BJ20150643 [pii]

20. Harrop SJ, Jankova L, Coles M, Jardine D, Whittaker JS, Gould AR, Meister A, King GC, Mabbutt BC, Curmi PM (1999) The crystal structure of plasminogen activator inhibitor 2 at 2.0 A resolution: implications for serpin function. Structure 7 (1):43-54. doi:S0969-2126(99)80008-2 [pii]

21. Huber R, Carrell RW (1989) Implications of the three-dimensional structure of alpha 1-antitrypsin for structure and function of serpins. Biochemistry 28 (23):8951-8966

22. Ryu SE, Choi HJ, Kwon KS, Lee KN, Yu MH (1996) The native strains in the hydrophobic core and flexible reactive loop of a serine protease inhibitor: crystal structure of an uncleaved alpha1-antitrypsin at 2.7 A. Structure 4 (10):1181-1192. doi:S0969-2126(96)00126-8 [pii]

23. Lee C, Park SH, Lee MY, Yu MH (2000) Regulation of protein function by native metastability. Proc Natl Acad Sci U S A 97 (14):7727-7731. doi:97/14/7727 [pii]

24. Irving JA, Pike RN, Lesk AM, Whisstock JC (2000) Phylogeny of the serpin superfamily: implications of patterns of amino acid conservation for structure and function. Genome Res 10 (12):1845-1864

25. Hopkins PC, Carrell RW, Stone SR (1993) Effects of mutations in the hinge region of serpins. Biochemistry 32 (30):7650-7657

26. Stein PE, Carrell RW (1995) What Do Dysfunctional Serpins Tell Us About Molecular Mobility and Disease. Nat Struct Biol 2 (2):96-113. doi:Doi 10.1038/Nsb0295-96

27. Gettins PGW, Olson ST (2016) Inhibitory serpins. New insights into their folding, polymerization, regulation and clearance. Biochemical Journal 473:2273-2293. doi:10.1042/Bcj20160014

28. Stoller JK, Aboussouan LS (2012) A review of alpha1-antitrypsin deficiency. Am J Respir Crit Care Med 185 (3):246-259. doi:10.1164/rccm.201108-1428Cl

201108-1428Cl [pii]

29. Lomas DA, Evans DL, Finch JT, Carrell RW (1992) The mechanism of $Z$ alpha 1-antitrypsin accumulation in the liver. Nature 357 (6379):605-607. doi:10.1038/357605a0

30. Wada J (2008) Vaspin: a novel serpin with insulin-sensitizing effects. Expert Opin Investig Drugs 17 (3):327-333. doi:10.1517/13543784.17.3.327

31. Athyros VG, Tziomalos K, Karagiannis A, Anagnostis P, Mikhailidis DP (2010) Should adipokines be considered in the choice of the treatment of obesity-related health problems? Curr Drug Targets 11 (1):122-135

32. Hida K, Wada J, Eguchi J, Zhang H, Baba M, Seida A, Hashimoto I, Okada T, Yasuhara A, Nakatsuka A, Shikata K, Hourai S, Futami J, Watanabe E, Matsuki Y, Hiramatsu R, Akagi S, Makino H, Kanwar YS (2005) Visceral adipose tissue-derived serine protease inhibitor: a unique insulin-sensitizing adipocytokine in obesity. Proc Natl Acad Sci U S A 102 (30):10610-10615. doi:0504703102 [pii]

10.1073/pnas.0504703102

33. Lundstrom A, Egelrud T (1991) Stratum corneum chymotryptic enzyme: a proteinase which may be generally present in the stratum corneum and with a possible involvement in desquamation. Acta Derm Venereol 71 (6):471-474

34. Ekholm E, Egelrud T (1999) Stratum corneum chymotryptic enzyme in psoriasis. Arch Dermatol Res 291 (4):195-200 
35. Yamasaki K, Di Nardo A, Bardan A, Murakami M, Ohtake T, Coda A, Dorschner RA, Bonnart C, Descargues P, Hovnanian A, Morhenn VB, Gallo RL (2007) Increased serine protease activity and cathelicidin promotes skin inflammation in rosacea. Nat Med 13 (8):975-980. doi:nm1616 [pii]

$10.1038 / \mathrm{nm} 1616$

36. Ulbricht D, Tindall CA, Oertwig K, Hanke S, Strater N, Heiker JT (2018) Kallikrein-related peptidase 14 is the second KLK protease targeted by the serpin vaspin. Biol Chem. doi:10.1515/hsz-2018-0108

/j/bchm.ahead-of-print/hsz-2018-0108/hsz-2018-0108.xml [pii]

/j/bchm.just-accepted/hsz-2018-0108/hsz-2018-0108.xml [pii]

37. de Veer SJ, Furio L, Swedberg JE, Munro CA, Brattsand M, Clements JA, Hovnanian A, Harris JM (2017) Selective Substrates and Inhibitors for Kallikrein-Related Peptidase 7 (KLK7) Shed Light on KLK Proteolytic Activity in the Stratum Corneum. J Invest Dermatol 137 (2):430-439. doi:S0022202X(16)32463-0 [pii]

10.1016/j.jid.2016.09.017

38. Debela M, Magdolen V, Schechter N, Valachova M, Lottspeich F, Craik CS, Choe Y, Bode W, Goettig $P(2006)$ Specificity profiling of seven human tissue kallikreins reveals individual subsite preferences. J Biol Chem 281 (35):25678-25688. doi:M602372200 [pii]

10.1074/jbc.M602372200

39. Oliveira JR, Bertolin TC, Andrade D, Oliveira LC, Kondo MY, Santos JA, Blaber M, Juliano L, Severino B, Caliendo G, Santagada V, Juliano MA (2015) Specificity studies on Kallikrein-related peptidase 7 (KLK7) and effects of osmolytes and glycosaminoglycans on its peptidase activity. Biochim Biophys Acta 1854 (1):73-83. doi:10.1016/j.bbapap.2014.10.018

S1570-9639(14)00278-7 [pii]

40. Ulbricht D, Oertwig K, Arnsburg K, Saalbach A, Pippel J, Strater N, Heiker JT (2017) Basic Residues of beta-Sheet A Contribute to Heparin Binding and Activation of Vaspin (Serpin A12). J Biol Chem 292

(3):994-1004. doi:10.1074/jbc.M116.748020

M116.748020 [pii]

41. Saalbach A, Tremel J, Herbert D, Schwede K, Wandel E, Schirmer C, Anderegg U, Beck-Sickinger AG, Heiker JT, Schultz S, Magin T, Simon JC (2016) Anti-Inflammatory Action of Keratinocyte-Derived Vaspin: Relevance for the Pathogenesis of Psoriasis. Am J Pathol 186 (3):639-651. doi:10.1016/j.ajpath.2015.10.030

S0002-9440(15)00660-4 [pii]

42. Nakatsuka A, Wada J, Iseda I, Teshigawara S, Higashio K, Murakami K, Kanzaki M, Inoue K, Terami T, Katayama A, Hida K, Eguchi J, Horiguchi CS, Ogawa D, Matsuki Y, Hiramatsu R, Yagita H, Kakuta S, Iwakura Y, Makino $\mathrm{H}$ (2012) Vaspin is an adipokine ameliorating ER stress in obesity as a ligand for cellsurface GRP78/MTJ-1 complex. Diabetes 61 (11):2823-2832. doi:10.2337/db12-0232

db12-0232 [pii]

43. Gonzalez-Gronow M, Cuchacovich M, Llanos C, Urzua C, Gawdi G, Pizzo SV (2006) Prostate cancer cell proliferation in vitro is modulated by antibodies against glucose-regulated protein 78 isolated from patient serum. Cancer Res 66 (23):11424-11431. doi:66/23/11424 [pii]

10.1158/0008-5472.CAN-06-1721

44. Haas IG (1994) BiP (GRP78), an essential hsp70 resident protein in the endoplasmic reticulum. Experientia 50 (11-12):1012-1020

45. Gonzalez-Gronow M, Selim MA, Papalas J, Pizzo SV (2009) GRP78: a multifunctional receptor on the cell surface. Antioxid Redox Signal 11 (9):2299-2306. doi:10.1089/ARS.2009.2568

46. Nakatsuka A, Wada J, Iseda I, Teshigawara S, Higashio K, Murakami K, Kanzaki M, Inoue K, Terami T, Katayama A, Hida K, Eguchi J, Ogawa D, Matsuki Y, Hiramatsu R, Yagita H, Kakuta S, Iwakura Y, Makino H (2013) Visceral adipose tissue-derived serine proteinase inhibitor inhibits apoptosis of 
endothelial cells as a ligand for the cell-surface GRP78/voltage-dependent anion channel complex. Circ Res 112 (5):771-780. doi:10.1161/CIRCRESAHA.111.300049

CIRCRESAHA.111.300049 [pii]

47. Misra UK, Gonzalez-Gronow M, Gawdi G, Pizzo SV (2005) The role of MTJ-1 in cell surface translocation of GRP78, a receptor for alpha 2-macroglobulin-dependent signaling. J Immunol 174 (4):2092-2097. doi:174/4/2092 [pii]

48. Misra UK, Gonzalez-Gronow M, Gawdi G, Wang F, Pizzo SV (2004) A novel receptor function for the heat shock protein Grp78: silencing of Grp78 gene expression attenuates alpha2M*-induced signalling. Cell Signal 16 (8):929-938. doi:10.1016/j.cellsig.2004.01.003

S0898656804000142 [pii]

49. Gonzalez-Gronow M, Kalfa T, Johnson CE, Gawdi G, Pizzo SV (2003) The voltage-dependent anion channel is a receptor for plasminogen kringle 5 on human endothelial cells. J Biol Chem 278 (29):2731227318. doi:10.1074/jbc.M303172200

M303172200 [pii]

50. Davidson DJ, Haskell C, Majest S, Kherzai A, Egan DA, Walter KA, Schneider A, Gubbins EF, Solomon L, Chen Z, Lesniewski R, Henkin J (2005) Kringle 5 of human plasminogen induces apoptosis of endothelial and tumor cells through surface-expressed glucose-regulated protein 78. Cancer Res 65 (11):4663-4672. doi:65/11/4663 [pii]

\subsection{8/0008-5472.CAN-04-3426}

51. Lu H, Dhanabal M, Volk R, Waterman MJ, Ramchandran R, Knebelmann B, Segal M, Sukhatme VP (1999) Kringle 5 causes cell cycle arrest and apoptosis of endothelial cells. Biochem Biophys Res Commun 258 (3):668-673. doi:S0006-291X(99)90612-5 [pii]

10.1006/bbrc.1999.0612

52. Gonzalez-Gronow M, Kaczowka SJ, Payne S, Wang F, Gawdi G, Pizzo SV (2007) Plasminogen structural domains exhibit different functions when associated with cell surface GRP78 or the voltagedependent anion channel. J Biol Chem 282 (45):32811-32820. doi:M703342200 [pii]

10.1074/jbc.M703342200

53. Oertwig K, Ulbricht D, Hanke S, Pippel J, Bellmann-Sickert K, Strater N, Heiker JT (2017) Glycosylation of human vaspin (SERPINA12) and its impact on serpin activity, heparin binding and thermal stability. Biochim Biophys Acta 1865 (9):1188-1194. doi:S1570-9639(17)30141-3 [pii]

10.1016/j.bbapap.2017.06.020

54. Shaker OG, Sadik NA (2013) Vaspin gene in rat adipose tissue: relation to obesity-induced insulin resistance. Mol Cell Biochem 373 (1-2):229-239. doi:10.1007/s11010-012-1494-5

55. Kloting N, Berndt J, Kralisch S, Kovacs P, Fasshauer M, Schon MR, Stumvoll M, Bluher M (2006) Vaspin gene expression in human adipose tissue: association with obesity and type 2 diabetes. Biochem Biophys Res Commun 339 (1):430-436. doi:S0006-291X(05)02557-X [pii]

10.1016/j.bbrc.2005.11.039

56. Lee JA, Park HS, Song YS, Jang YJ, Kim JH, Lee YJ, Heo YS (2011) Relationship between vaspin gene expression and abdominal fat distribution of Korean women. Endocr J 58 (8):639-646. doi:JST.JSTAGE/endocrj/K11E-073 [pii]

57. Fain JN, Buehrer B, Bahouth SW, Tichansky DS, Madan AK (2008) Comparison of messenger RNA distribution for 60 proteins in fat cells vs the nonfat cells of human omental adipose tissue. Metabolism 57 (7):1005-1015. doi:10.1016/j.metabol.2008.02.019

S0026-0495(08)00090-5 [pii]

58. Weiner J, Rohde K, Krause K, Zieger K, Kloting N, Kralisch S, Kovacs P, Stumvoll M, Bluher M, Bottcher Y, Heiker JT (2017) Brown adipose tissue (BAT) specific vaspin expression is increased after obesogenic diets and cold exposure and linked to acute changes in DNA-methylation. Mol Metab 6 (6):482-493. doi:10.1016/j.molmet.2017.03.004 
S2212-8778(17)30111-4 [pii]

59. Saalbach A, Vester K, Rall K, Tremel J, Anderegg U, Beck-Sickinger AG, Bluher M, Simon JC (2012) Vaspin--a link of obesity and psoriasis? Exp Dermatol 21 (4):309-312. doi:10.1111/j.16000625.2012.01460.x

60. Toulza E, Mattiuzzo NR, Galliano MF, Jonca N, Dossat C, Jacob D, de Daruvar A, Wincker P, Serre G, Guerrin M (2007) Large-scale identification of human genes implicated in epidermal barrier function. Genome Biol 8 (6):R107. doi:gb-2007-8-6-r107 [pii]

\subsection{6/gb-2007-8-6-r107}

61. Korner A, Neef M, Friebe D, Erbs S, Kratzsch J, Dittrich K, Bluher S, Kapellen TM, Kovacs P, Stumvoll $\mathrm{M}$, Bluher $\mathrm{M}$, Kiess W (2011) Vaspin is related to gender, puberty and deteriorating insulin sensitivity in children. Int J Obes (Lond) 35 (4):578-586. doi:10.1038/ijo.2010.196

ijo2010196 [pii]

62. Caminos JE, Bravo SB, Garces MF, Gonzalez CR, Cepeda LA, Gonzalez AC, Nogueiras R, Gallego R, Garcia-Caballero T, Cordido F, Lopez M, Dieguez C (2009) Vaspin and amylin are expressed in human and rat placenta and regulated by nutritional status. Histol Histopathol 24 (8):979-990. doi:10.14670/HH-24.979

63. Kloting N, Kovacs P, Kern M, Heiker JT, Fasshauer M, Schon MR, Stumvoll M, Beck-Sickinger AG, Bluher M (2011) Central vaspin administration acutely reduces food intake and has sustained blood glucose-lowering effects. Diabetologia 54 (7):1819-1823. doi:10.1007/s00125-011-2137-1

64. Feng R, Li Y, Wang C, Luo C, Liu L, Chuo F, Li Q, Sun C (2014) Higher vaspin levels in subjects with obesity and type 2 diabetes mellitus: a meta-analysis. Diabetes Res Clin Pract 106 (1):88-94. doi:10.1016/j.diabres.2014.07.026

S0168-8227(14)00320-9 [pii]

65. Teshigawara S, Wada J, Hida K, Nakatsuka A, Eguchi J, Murakami K, Kanzaki M, Inoue K, Terami T, Katayama A, Iseda I, Matsushita Y, Miyatake N, McDonald JF, Hotta K, Makino H (2012) Serum vaspin concentrations are closely related to insulin resistance, and rs77060950 at SERPINA12 genetically defines distinct group with higher serum levels in Japanese population. J Clin Endocrinol Metab 97 (7):E1202-1207. doi:10.1210/jc.2011-3297

jc.2011-3297 [pii]

66. Youn BS, Kloting N, Kratzsch J, Lee N, Park JW, Song ES, Ruschke K, Oberbach A, Fasshauer M, Stumvoll M, Bluher $M(2008)$ Serum vaspin concentrations in human obesity and type 2 diabetes. Diabetes 57 (2):372-377. doi:db07-1045 [pii]

\section{$10.2337 / \mathrm{db} 07-1045$}

67. Jian W, Peng W, Xiao S, Li H, Jin J, Qin L, Dong Y, Su Q (2014) Role of serum vaspin in progression of type 2 diabetes: a 2-year cohort study. PLoS One 9 (4):e94763. doi:10.1371/journal.pone.0094763

PONE-D-13-40577 [pii]

68. Cho JK, Han TK, Kang HS (2010) Combined effects of body mass index and cardio/respiratory fitness on serum vaspin concentrations in Korean young men. Eur J Appl Physiol 108 (2):347-353. doi:10.1007/s00421-009-1238-8

69. Derosa G, Fogari E, D'Angelo A, Bianchi L, Bonaventura A, Romano D, Maffioli P (2013) Adipocytokine levels in obese and non-obese subjects: an observational study. Inflammation 36 (4):914-920. doi:10.1007/s10753-013-9620-4

70. Zhang L, Li L, Yang M, Liu H, Yang G (2011) Elevated circulating vaspin levels were decreased by rosiglitazone therapy in T2DM patients with poor glycemic control on metformin alone. Cytokine 56 (2):399-402. doi:10.1016/j.cyto.2011.07.003

S1043-4666(11)00222-5 [pii]

71. Seeger J, Ziegelmeier M, Bachmann A, Lossner U, Kratzsch J, Bluher M, Stumvoll M, Fasshauer M (2008) Serum levels of the adipokine vaspin in relation to metabolic and renal parameters. J Clin Endocrinol Metab 93 (1):247-251. doi:jc.2007-1853 [pii]

10.1210/jc.2007-1853 
72. Jeong E, Youn BS, Kim DW, Kim EH, Park JW, Namkoong C, Jeong JY, Yoon SY, Park JY, Lee KU, Kim MS (2010) Circadian rhythm of serum vaspin in healthy male volunteers: relation to meals. J Clin Endocrinol Metab 95 (4):1869-1875. doi:10.1210/jc.2009-1088

jc.2009-1088 [pii]

73. Gulcelik NE, Karakaya J, Gedik A, Usman A, Gurlek A (2009) Serum vaspin levels in type 2 diabetic women in relation to microvascular complications. Eur J Endocrinol 160 (1):65-70. doi:10.1530/EJE-080723

\section{EJE-08-0723 [pii]}

74. Golpaie A, Tajik N, Masoudkabir F, Karbaschian Z, Talebpour M, Hoseini M, Hosseinzadeh-Attar MJ (2011) Short-term effect of weight loss through restrictive bariatric surgery on serum levels of vaspin in morbidly obese subjects. Eur Cytokine Netw 22 (4):181-186. doi:10.1684/ecn.2011.0295

ecn.2011.0295 [pii]

75. Handisurya A, Riedl M, Vila G, Maier C, Clodi M, Prikoszovich T, Ludvik B, Prager G, Luger A, KautzkyWiller A (2010) Serum vaspin concentrations in relation to insulin sensitivity following RYGB-induced weight loss. Obes Surg 20 (2):198-203. doi:10.1007/s11695-009-9882-y

76. Lu H, Fouejeu Wamba PC, Lapointe M, Poirier P, Martin J, Bastien M, Cianflone K (2014) Increased vaspin levels are associated with beneficial metabolic outcome pre- and post-bariatric surgery. PLoS One 9 (10):e111002. doi:10.1371/journal.pone.0111002

PONE-D-14-16625 [pii]

77. Vink RG, Roumans NJ, Mariman EC, van Baak MA (2017) Dietary weight loss-induced changes in RBP4, FFA, and ACE predict weight regain in people with overweight and obesity. Physiol Rep 5 (21). doi:e13450 [pii]

$10.14814 /$ phy2.13450

5/21/e13450 [pii]

78. Bluher M, Rudich A, Kloting N, Golan R, Henkin Y, Rubin E, Schwarzfuchs D, Gepner Y, Stampfer MJ, Fiedler M, Thiery J, Stumvoll M, Shai I (2012) Two patterns of adipokine and other biomarker dynamics in a long-term weight loss intervention. Diabetes Care 35 (2):342-349. doi:10.2337/dc11-1267

dc11-1267 [pii]

79. Chang HM, Lee HJ, Park HS, Kang JH, Kim KS, Song YS, Jang YJ (2010) Effects of weight reduction on serum vaspin concentrations in obese subjects: modification by insulin resistance. Obesity (Silver Spring) 18 (11):2105-2110. doi:10.1038/oby.2010.60

oby201060 [pii]

80. Koiou E, Tziomalos K, Dinas K, Katsikis I, Kalaitzakis E, Delkos D, Kandaraki EA, Panidis D (2011) The effect of weight loss and treatment with metformin on serum vaspin levels in women with polycystic ovary syndrome. Endocr J 58 (4):237-246. doi:JST.JSTAGE/endocrj/K10E-330 [pii]

81. Breitfeld J, Tonjes A, Bottcher Y, Schleinitz D, Wiele N, Marzi C, Brockhaus C, Rathmann W, Huth C, Grallert H, Illig T, Bluher M, Kovacs P, Stumvoll M (2013) Genetic variation in the vaspin gene affects circulating serum vaspin concentrations. Int J Obes (Lond) 37 (6):861-866. doi:10.1038/ijo.2012.133

ijo2012133 [pii]

82. Breitfeld J, Heiker JT, Bottcher Y, Schleinitz D, Tonjes A, Weidle K, Krause K, Kuettner EB, Scholz M, Kiess W, Strater N, Beck-Sickinger AG, Stumvoll M, Korner A, Bluher M, Kovacs P (2013) Analysis of a rare functional truncating mutation rs61757459 in vaspin (SERPINA12) on circulating vaspin levels. J Mol Med (Berl) 91 (11):1285-1292. doi:10.1007/s00109-013-1062-9

83. Kempf K, Rose B, Illig T, Rathmann W, Strassburger K, Thorand B, Meisinger C, Wichmann HE, Herder C, Vollmert C (2010) Vaspin (SERPINA12) genotypes and risk of type 2 diabetes: Results from the MONICA/KORA studies. Exp Clin Endocrinol Diabetes 118 (3):184-189. doi:10.1055/s-20081081499 
84. Maekawa H, Tollefsen DM (1996) Role of the proposed serpin-enzyme complex receptor recognition site in binding and internalization of thrombin-heparin cofactor II complexes by hepatocytes. J Biol Chem 271 (31):18604-18609

85. Mast AE, Enghild JJ, Pizzo SV, Salvesen G (1991) Analysis of the plasma elimination kinetics and conformational stabilities of native, proteinase-complexed, and reactive site cleaved serpins: comparison of alpha 1-proteinase inhibitor, alpha 1-antichymotrypsin, antithrombin III, alpha 2antiplasmin, angiotensinogen, and ovalbumin. Biochemistry 30 (6):1723-1730

86. Ebert T, Gebhardt C, Scholz M, Wohland T, Schleinitz D, Fasshauer M, Bluher M, Stumvoll M, Kovacs P, Tonjes A (2018) Relationship Between 12 Adipocytokines and Distinct Components of the Metabolic Syndrome. J Clin Endocrinol Metab 103 (3):1015-1023. doi:10.1210/jc.2017-02085

4794883 [pii]

87. Lustig RH (2017) Processed Food-An Experiment That Failed. JAMA Pediatr 171 (3):212-214. doi:10.1001/jamapediatrics.2016.4136

2598465 [pii]

88. Chopra M, Siddhu A, Tandon N (2014) Effect of Nutritional Regulation on Adipokines in Obesity: A Review. American Journal of Food and Nutrition 2 (4):66-70

89. Castro CA, da Silva KA, Buffo MM, Pinto KNZ, Duarte FO, Nonaka KO, Anibal FF, Duarte A (2017) Experimental type 2 diabetes induction reduces serum vaspin, but not serum omentin, in Wistar rats. Int J Exp Pathol 98 (1):26-33. doi:10.1111/iep.12220

90. Gonzalez CR, Caminos JE, Vazquez MJ, Garces MF, Cepeda LA, Angel A, Gonzalez AC, GarciaRendueles ME, Sangiao-Alvarellos S, Lopez M, Bravo SB, Nogueiras R, Dieguez C (2009) Regulation of visceral adipose tissue-derived serine protease inhibitor by nutritional status, metformin, gender and pituitary factors in rat white adipose tissue. J Physiol 587 (Pt 14):3741-3750. doi:10.1113/jphysiol.2009.172510

jphysiol.2009.172510 [pii]

91. Breitfeld J, Tonjes A, Gast MT, Schleinitz D, Bluher M, Stumvoll M, Kovacs P, Bottcher Y (2013) Role of vaspin in human eating behaviour. PLoS One 8 (1):e54140. doi:10.1371/journal.pone.0054140

PONE-D-12-28416 [pii]

92. Ostrowska Z, Ziora K, Oswiecimska J, Swietochowska E, Marek B, Kajdaniuk D, Strzelczyk J, Golabek K, Morawiecka-Pietrzak M, Wolkowska-Pokrywa K, Kos-Kudla B (2016) Vaspin and selected indices of bone status in girls with anorexia nervosa. Endokrynol Pol 67 (6):599-606. doi:10.5603/EP.2016.0070

VM/OJS/J/45155 [pii]

93. Vehapoglu A, Ustabas F, Ozgen TI, Terzioglu S, Cermik BB, Ozen OF (2015) Role of circulating adipocytokines vaspin, apelin, and visfatin in the loss of appetite in underweight children: a pilot trial. J Pediatr Endocrinol Metab 28 (9-10):1065-1071. doi:10.1515/jpem-2014-0490

/j/jpem.2015.28.issue-9-10/jpem-2014-0490/jpem-2014-0490.xml [pii]

/j/jpem.ahead-of-print/jpem-2014-0490/jpem-2014-0490.xml [pii]

94. Kang ES, Magkos F, Sienkiewicz E, Mantzoros CS (2011) Circulating vaspin and visfatin are not affected by acute or chronic energy deficiency or leptin administration in humans. Eur J Endocrinol 164 (6):911-917. doi:10.1530/EJE-11-0052

EJE-11-0052 [pii]

95. Boden G, Chen X, Mozzoli M, Ryan I (1996) Effect of fasting on serum leptin in normal human subjects. J Clin Endocrinol Metab 81 (9):3419-3423. doi:10.1210/jcem.81.9.8784108

96. Chen M, Deng D, Fang Z, Xu M, Hu H, Luo L, Wang Y (2014) Fenofibrate increases serum vaspin by upregulating its expression in adipose tissue. Endocrine 45 (3):409-421. doi:10.1007/s12020-0130023-y

97. Tan BK, Heutling D, Chen J, Farhatullah S, Adya R, Keay SD, Kennedy CR, Lehnert H, Randeva HS (2008) Metformin decreases the adipokine vaspin in overweight women with polycystic ovary syndrome concomitant with improvement in insulin sensitivity and a decrease in insulin resistance. Diabetes 57 (6):1501-1507. doi:10.2337/db08-0127 
db08-0127 [pii]

98. Kadoglou NP, Kapelouzou A, Tsanikidis H, Vitta I, Liapis CD, Sailer N (2011) Effects of rosiglitazone/metformin fixed-dose combination therapy and metformin monotherapy on serum vaspin, adiponectin and IL- 6 levels in drug-naive patients with type 2 diabetes. Exp Clin Endocrinol Diabetes 119 (2):63-68. doi:10.1055/s-0030-1265174

99. Li K, Li L, Yang M, Liu H, Liu D, Yang H, Boden G, Yang G (2011) Short-term continuous subcutaneous insulin infusion decreases the plasma vaspin levels in patients with type 2 diabetes mellitus concomitant with improvement in insulin sensitivity. Eur J Endocrinol 164 (6):905-910. doi:10.1530/EJE-10-1023

EJE-10-1023 [pii]

100. Kovacs P, Miehle K, Sandner B, Stumvoll M, Bluher M (2013) Insulin administration acutely decreases vaspin serum concentrations in humans. Obes Facts 6 (1):86-88. doi:10.1159/000348836

000348836 [pii]

101. Cinar N, Gulcelik NE, Aydin K, Akin S, Usman A, Gurlek A (2011) Serum vaspin levels in hypothyroid patients. Eur J Endocrinol 165 (4):563-569. doi:10.1530/EJE-11-0180

EJE-11-0180 [pii]

102. von Loeffelholz C, Mohlig M, Arafat AM, Isken F, Spranger J, Mai K, Randeva HS, Pfeiffer AFH, Weickert MO (2010) Circulating vaspin is unrelated to insulin sensitivity in a cohort of nondiabetic humans. European Journal of Endocrinology 162 (3):507-513. doi:10.1530/Eje-09-0737

103. Ibanez L, Lopez-Bermejo A, Diaz M, Enriquez G, del Rio L, de Zegher F (2009) Low-dose pioglitazone and low-dose flutamide added to metformin and oestro-progestagens for hyperinsulinaemic women with androgen excess: add-on benefits disclosed by a randomized double-placebo study over 24 months. Clin Endocrinol 71 (3):351-357. doi:10.1111/j.1365-2265.2008.03472.x

104. Cakal E, Ustun Y, Engin-Ustun Y, Ozkaya M, Kilinc M (2011) Serum vaspin and C-reactive protein levels in women with polycystic ovaries and polycystic ovary syndrome. Gynecol Endocrinol 27 (7):491495. doi:10.3109/09513590.2010.501874

105. Guvenc Y, Var A, Goker A, Kuscu NK (2016) Assessment of serum chemerin, vaspin and omentin1 levels in patients with polycystic ovary syndrome. J Int Med Res 44 (4):796-805. doi:10.1177/0300060516645421

0300060516645421 [pii]

106. Akbarzadeh S, Nabipour I, Jafari SM, Movahed A, Motamed N, Assadi M, Hajian N (2012) Serum visfatin and vaspin levels in normoglycemic first-degree relatives of Iranian patients with type 2 diabetes mellitus. Diabetes Res Clin Pract 95 (1):132-138. doi:10.1016/j.diabres.2011.10.004

S0168-8227(11)00543-2 [pii]

107. Rojas J, Chavez M, Olivar L, Rojas M, Morillo J, Mejias J, Calvo M, Bermudez V (2014) Polycystic ovary syndrome, insulin resistance, and obesity: navigating the pathophysiologic labyrinth. Int J Reprod Med 2014:719050. doi:10.1155/2014/719050

108. Koiou E, Dinas K, Tziomalos K, Toulis K, Kandaraki EA, Kalaitzakis E, Katsikis I, Panidis D (2011) The phenotypes of polycystic ovary syndrome defined by the 1990 diagnostic criteria are associated with higher serum vaspin levels than the phenotypes introduced by the 2003 criteria. Obes Facts 4 (2):145150. doi:10.1159/000327935

000327935 [pii]

109. Zieger K, Weiner J, Kunath A, Gericke M, Krause K, Kern M, Stumvoll M, Kloting N, Bluher M, Heiker JT (2017) Ablation of kallikrein 7 (KLK7) in adipose tissue ameliorates metabolic consequences of high fat diet-induced obesity by counteracting adipose tissue inflammation in vivo. Cell Mol Life Sci. doi:10.1007/s00018-017-2658-y

10.1007/s00018-017-2658-y [pii]

110. Liu P, Li G, Wu J, Zhou X, Wang L, Han W, Lv Y, Sun C (2015) Vaspin promotes 3T3-L1 preadipocyte differentiation. Exp Biol Med (Maywood) 240 (11):1520-1527. doi:10.1177/1535370214565081

1535370214565081 [pii] 
111. Zieger K, Weiner J, Krause K, Schwarz M, Kohn M, Stumvoll M, Bluher M, Heiker JT (2017) Vaspin suppresses cytokine-induced inflammation in 3T3-L1 adipocytes via inhibition of NFkappaB pathway. Mol Cell Endocrinol. doi:S0303-7207(17)30395-7 [pii]

10.1016/j.mce.2017.07.022

112. Harms M, Seale P (2013) Brown and beige fat: development, function and therapeutic potential. Nat Med 19 (10):1252-1263. doi:10.1038/nm.3361

nm.3361 [pii]

113. Bhatt PS, Dhillo WS, Salem V (2017) Human brown adipose tissue-function and therapeutic potential in metabolic disease. Curr Opin Pharmacol 37:1-9. doi:S1471-4892(17)30105-4 [pii]

10.1016/j.coph.2017.07.004

114. Rothwell NJ, Stock MJ (1979) A role for brown adipose tissue in diet-induced thermogenesis. Nature 281 (5726):31-35

115. Kajimura S, Saito M (2014) A new era in brown adipose tissue biology: molecular control of brown fat development and energy homeostasis. Annu Rev Physiol 76:225-249. doi:10.1146/annurev-physiol021113-170252

116. Tamucci KA, Namwanje M, Fan L, Qiang L (2017) The dark side of browning. Protein Cell. doi:10.1007/s13238-017-0434-2

10.1007/s13238-017-0434-2 [pii]

117. Rosell M, Kaforou M, Frontini A, Okolo A, Chan YW, Nikolopoulou E, Millership S, Fenech ME, MacIntyre D, Turner JO, Moore JD, Blackburn E, Gullick WJ, Cinti S, Montana G, Parker MG, Christian $M(2014)$ Brown and white adipose tissues: intrinsic differences in gene expression and response to cold exposure in mice. Am J Physiol Endocrinol Metab 306 (8): E945-964. doi:10.1152/ajpendo.00473.2013

ajpendo.00473.2013 [pii]

118. Fu BD, Yamawaki H, Okada M, Hara Y (2009) Vaspin can not inhibit TNF-alpha-induced inflammation of human umbilical vein endothelial cells. J Vet Med Sci 71 (9):1201-1207. doi:JST.JSTAGE/jvms/71.1201 [pii]

119. Phalitakul S, Okada M, Hara Y, Yamawaki H (2011) Vaspin prevents TNF-alpha-induced intracellular adhesion molecule-1 via inhibiting reactive oxygen species-dependent NF-kappaB and PKCtheta activation in cultured rat vascular smooth muscle cells. Pharmacol Res 64 (5):493-500. doi:10.1016/j.phrs.2011.06.001

S1043-6618(11)00167-8 [pii]

120. Jung CH, Lee MJ, Kang YM, Lee YL, Yoon HK, Kang SW, Lee WJ, Park JY (2014) Vaspin inhibits cytokine-induced nuclear factor-kappa B activation and adhesion molecule expression via AMPactivated protein kinase activation in vascular endothelial cells. Cardiovasc Diabetol 13:41. doi:10.1186/1475-2840-13-41

1475-2840-13-41 [pii]

121. Liu S, Dong Y, Wang T, Zhao S, Yang K, Chen X, Zheng C (2014) Vaspin inhibited proinflammatory cytokine induced activation of nuclear factor-kappa $B$ and its downstream molecules in human endothelial EA.hy926 cells. Diabetes Res Clin Pract 103 (3):482-488. doi:10.1016/j.diabres.2013.12.002

S0168-8227(13)00435-X [pii]

122. Sakamoto Y, Kameshima S, Kakuda C, Okamura Y, Kodama T, Okada M, Yamawaki H (2017) Visceral adipose tissue-derived serine protease inhibitor prevents the development of monocrotalineinduced pulmonary arterial hypertension in rats. Pflugers Arch. doi:10.1007/s00424-017-2043-6

10.1007/s00424-017-2043-6 [pii]

123. Jung CH, Lee WJ, Hwang JY, Seol SM, Kim YM, Lee YL, Park JY (2011) Vaspin protects vascular endothelial cells against free fatty acid-induced apoptosis through a phosphatidylinositol 3-kinase/Akt pathway. Biochem Biophys Res Commun 413 (2):264-269. doi:10.1016/j.bbrc.2011.08.083 
S0006-291X(11)01492-6 [pii]

124. Li H, Peng W, Zhuang J, Lu Y, Jian W, Wei Y, Li W, Xu Y (2013) Vaspin attenuates high glucoseinduced vascular smooth muscle cells proliferation and chemokinesis by inhibiting the MAPK, PI3K/Akt, and NF-kappaB signaling pathways. Atherosclerosis 228 (1):61-68. doi:10.1016/j.atherosclerosis.2013.02.013

S0021-9150(13)00123-8 [pii]

125. Cai W, Ramdas M, Zhu L, Chen X, Striker GE, Vlassara H (2012) Oral advanced glycation endproducts (AGEs) promote insulin resistance and diabetes by depleting the antioxidant defenses AGE receptor-1 and sirtuin 1. Proc Natl Acad Sci U S A 109 (39):15888-15893. doi:1205847109 [pii]

\subsection{3/pnas.1205847109}

126. Vulesevic B, McNeill B, Giacco F, Maeda K, Blackburn NJ, Brownlee M, Milne RW, Suuronen EJ (2016) Methylglyoxal-Induced Endothelial Cell Loss and Inflammation Contribute to the Development of Diabetic Cardiomyopathy. Diabetes 65 (6):1699-1713. doi:10.2337/db15-0568

db15-0568 [pii]

127. Phalitakul S, Okada M, Hara Y, Yamawaki H (2013) Vaspin prevents methylglyoxal-induced apoptosis in human vascular endothelial cells by inhibiting reactive oxygen species generation. Acta Physiol (Oxf) 209 (3):212-219. doi:10.1111/apha.12139

128. Deanfield JE, Halcox JP, Rabelink TJ (2007) Endothelial function and dysfunction: testing and clinical relevance. Circulation 115 (10):1285-1295. doi:115/10/1285 [pii]

\subsection{1/CIRCULATIONAHA.106.652859}

129. Van Gaal LF, Mertens IL, De Block CE (2006) Mechanisms linking obesity with cardiovascular disease. Nature 444 (7121):875-880. doi:nature05487 [pii]

$10.1038 /$ nature05487

130. Phalitakul S, Okada M, Hara Y, Yamawaki H (2012) A novel adipocytokine, vaspin inhibits plateletderived growth factor-BB-induced migration of vascular smooth muscle cells. Biochem Biophys Res Commun 423 (4):844-849. doi:10.1016/j.bbrc.2012.06.052

S0006-291X(12)01140-0 [pii]

131. Jung CH, Lee WJ, Hwang JY, Lee MJ, Seol SM, Kim YM, Lee YL, Kim HS, Kim MS, Park JY (2012) Vaspin increases nitric oxide bioavailability through the reduction of asymmetric dimethylarginine in vascular endothelial cells. PLoS One 7 (12):e52346. doi:10.1371/journal.pone.0052346

PONE-D-12-23093 [pii]

132. Sun $N$, Wang $H$, Wang $L$ (2015) Vaspin alleviates dysfunction of endothelial progenitor cells induced by high glucose via PI3K/Akt/eNOS pathway. Int J Clin Exp Pathol 8 (1):482-489

133. Kameshima S, Yamada K, Morita T, Okada M, Yamawaki H (2016) Visceral adipose tissue-derived serine protease inhibitor augments acetylcholine-induced relaxation via the inhibition of acetylcholine esterase activity in rat isolated mesenteric artery. Acta Physiol (Oxf) 216 (2):203-210. doi:10.1111/apha.12563

134. Kameshima S, Sakamoto Y, Okada M, Yamawaki H (2016) Vaspin prevents elevation of blood pressure through inhibition of peripheral vascular remodelling in spontaneously hypertensive rats. Acta Physiol (Oxf) 217 (2):120-129. doi:10.1111/apha.12636

135. Lin Y, Zhuang J, Li H, Zhu G, Zhou S, Li W, Peng W, Xu Y (2016) Vaspin attenuates the progression of atherosclerosis by inhibiting ER stress-induced macrophage apoptosis in apoE/ mice. Mol Med Rep 13 (2):1509-1516. doi:10.3892/mmr.2015.4708

136. Qi D, Wang D, Zhang C, Tang X, He J, Zhao Y, Deng W, Deng X (2017) Vaspin protects against LPSinduced ARDS by inhibiting inflammation, apoptosis and reactive oxygen species generation in pulmonary endothelial cells via the Akt/GSK3beta pathway. Int J Mol Med. doi:10.3892/ijmm.2017.3176

137. Ahima RS, Lazar MA (2008) Adipokines and the peripheral and neural control of energy balance. Mol Endocrinol 22 (5):1023-1031. doi:10.1210/me.2007-0529

me.2007-0529 [pii] 
138. Varela L, Horvath TL (2012) Leptin and insulin pathways in POMC and AgRP neurons that modulate energy balance and glucose homeostasis. EMBO Rep 13 (12):1079-1086. doi:10.1038/embor.2012.174

embor2012174 [pii]

139. Brunetti L, Di Nisio C, Recinella L, Chiavaroli A, Leone S, Ferrante C, Orlando G, Vacca M (2011) Effects of vaspin, chemerin and omentin-1 on feeding behavior and hypothalamic peptide gene expression in the rat. Peptides 32 (9):1866-1871. doi:10.1016/j.peptides.2011.08.003

S0196-9781(11)00322-6 [pii]

140. Luo X, Li K, Zhang C, Yang G, Yang M, Jia Y, Zhang L, Ma ZA, Boden G, Li L (2016) Central administration of vaspin inhibits glucose production and augments hepatic insulin signaling in high-fatdiet-fed rat. Int J Obes (Lond) 40 (6):947-954. doi:10.1038/ijo.2016.24

ijo201624 [pii]

141. Morgan JI, Cohen DR, Hempstead JL, Curran T (1987) Mapping patterns of c-fos expression in the central nervous system after seizure. Science 237 (4811):192-197

142. Filippi BM, Bassiri A, Abraham MA, Duca FA, Yue JT, Lam TK (2014) Insulin signals through the dorsal vagal complex to regulate energy balance. Diabetes 63 (3):892-899. doi:10.2337/db13-1044

db13-1044 [pii]

143. Chen W, Balland E, Cowley MA (2017) Hypothalamic Insulin Resistance in Obesity: Effects on Glucose Homeostasis. Neuroendocrinology 104 (4):364-381. doi:10.1159/000455865

000455865 [pii]

144. Gomez-Ambrosi J, Rodriguez A, Catalan V, Fruhbeck G (2008) The bone-adipose axis in obesity and weight loss. Obes Surg 18 (9):1134-1143. doi:10.1007/s11695-008-9548-1

145. Ozgen M, Koca SS, Dagli N, Balin M, Ustundag B, Isik A (2010) Serum adiponectin and vaspin levels in rheumatoid arthritis. Arch Med Res 41 (6):457-463. doi:10.1016/j.arcmed.2010.08.012

S0188-4409(10)00260-2 [pii]

146. Senolt L, Polanska M, Filkova M, Cerezo LA, Pavelka K, Gay S, Haluzik M, Vencovsky J (2010) Vaspin and omentin: new adipokines differentially regulated at the site of inflammation in rheumatoid arthritis. Ann Rheum Dis 69 (7):1410-1411. doi:10.1136/ard.2009.119735

$\operatorname{ard} .2009 .119735$ [pii]

147. Maijer KI, Neumann E, Muller-Ladner U, Drop DA, Ramwadhdoebe TH, Choi IY, Gerlag DM, de Hair MJ, Tak PP (2015) Serum Vaspin Levels Are Associated with the Development of Clinically Manifest Arthritis in Autoantibody-Positive Individuals. PLoS One 10 (12):e0144932. doi:10.1371/journal.pone.0144932

PONE-D-15-33311 [pii]

148. Assadi M, Salimipour H, Akbarzadeh S, Nemati R, Jafari SM, Bargahi A, Samani Z, Seyedabadi M, Sanjdideh Z, Nabipour I (2011) Correlation of circulating omentin-1 with bone mineral density in multiple sclerosis: the crosstalk between bone and adipose tissue. PLoS One 6 (9):e24240. doi:10.1371/journal.pone.0024240

PONE-D-11-10962 [pii]

149. Terzoudis S, Malliaraki N, Damilakis J, Dimitriadou DA, Zavos C, Koutroubakis IE (2016) Chemerin, visfatin, and vaspin serum levels in relation to bone mineral density in patients with inflammatory bowel disease. Eur J Gastroenterol Hepatol 28 (7):814-819. doi:10.1097/MEG.0000000000000617

150. Tanna N, Patel K, Moore AE, Dulnoan D, Edwards S, Hampson G (2017) The relationship between circulating adiponectin, leptin and vaspin with bone mineral density (BMD), arterial calcification and stiffness: a cross-sectional study in post-menopausal women. J Endocrinol Invest. doi:10.1007/s40618017-0711-1

10.1007/s40618-017-0711-1 [pii] 
151. Zhu X, Jiang Y, Shan PF, Shen J, Liang QH, Cui RR, Liu Y, Liu GY, Wu SS, Lu Q, Xie H, Liu YS, Yuan LQ, Liao EY (2013) Vaspin attenuates the apoptosis of human osteoblasts through ERK signaling pathway. Amino Acids 44 (3):961-968. doi:10.1007/s00726-012-1425-5

152. Liu Y, Xu F, Pei HX, Zhu X, Lin X, Song CY, Liang QH, Liao EY, Yuan LQ (2016) Vaspin regulates the osteogenic differentiation of MC3T3-E1 through the PI3K-Akt/miR-34c loop. Sci Rep 6:25578. doi:10.1038/srep25578

srep25578 [pii]

153. Kamio N, Kawato T, Tanabe N, Kitami S, Morita T, Ochiai K, Maeno M (2013) Vaspin attenuates RANKL-induced osteoclast formation in RAW264.7 cells. Connect Tissue Res 54 (2):147-152. doi:10.3109/03008207.2012.761978

154. Azfar RS, Gelfand JM (2008) Psoriasis and metabolic disease: epidemiology and pathophysiology. Curr Opin Rheumatol 20 (4):416-422. doi:10.1097/BOR.0b013e3283031c99

00002281-200807000-00008 [pii]

155. Ataseven A, Kesli R (2016) Novel inflammatory markers in psoriasis vulgaris: vaspin, vascular adhesion protein-1 (VAP-1), and YKL-40. G Ital Dermatol Venereol 151 (3):244-250. doi:R23Y9999N00A140048 [pii]

156. Miura S, Asano Y, Saigusa R, Yamashita T, Taniguchi T, Takahashi T, Ichimura Y, Toyama T, Tamaki Z, Tada Y, Sugaya M, Sato S, Kadono T (2015) Serum vaspin levels: A possible correlation with digital ulcers in patients with systemic sclerosis. J Dermatol 42 (5):528-531. doi:10.1111/1346-8138.12810

157. Schultz S, Saalbach A, Heiker JT, Meier R, Zellmann T, Simon JC, Beck-Sickinger AG (2013) Proteolytic activation of prochemerin by kallikrein 7 breaks an ionic linkage and results in C-terminal rearrangement. Biochem J 452 (2):271-280. doi:10.1042/BJ20121880

BJ20121880 [pii]

158. Debela M, Hess P, Magdolen V, Schechter NM, Steiner T, Huber R, Bode W, Goettig P (2007) Chymotryptic specificity determinants in the $1.0 \mathrm{~A}$ structure of the zinc-inhibited human tissue kallikrein 7. Proc Natl Acad Sci U S A 104 (41):16086-16091. doi:0707811104 [pii]

10.1073/pnas.0707811104

159. Mottarella SE, Beglov D, Beglova N, Nugent MA, Kozakov D, Vajda S (2014) Docking server for the identification of heparin binding sites on proteins. J Chem Inf Model 54 (7):2068-2078. doi:10.1021/ci500115j

160. Blom N, Sicheritz-Ponten T, Gupta R, Gammeltoft S, Brunak S (2004) Prediction of posttranslational glycosylation and phosphorylation of proteins from the amino acid sequence. Proteomics 4 (6):1633-1649. doi:10.1002/pmic.200300771

161. Bohne-Lang A, von der Lieth CW (2005) GlyProt: in silico glycosylation of proteins. Nucleic Acids Res 33 (Web Server issue):W214-219. doi:33/suppl_2/W214 [pii]

10.1093/nar/gki385

162. Yamasaki M, Takahashi N, Hirose M (2003) Crystal structure of S-ovalbumin as a non-loop-inserted thermostabilized serpin form. Journal of Biological Chemistry 278 (37):35524-35530. doi:10.1074/jbc.M305926200 


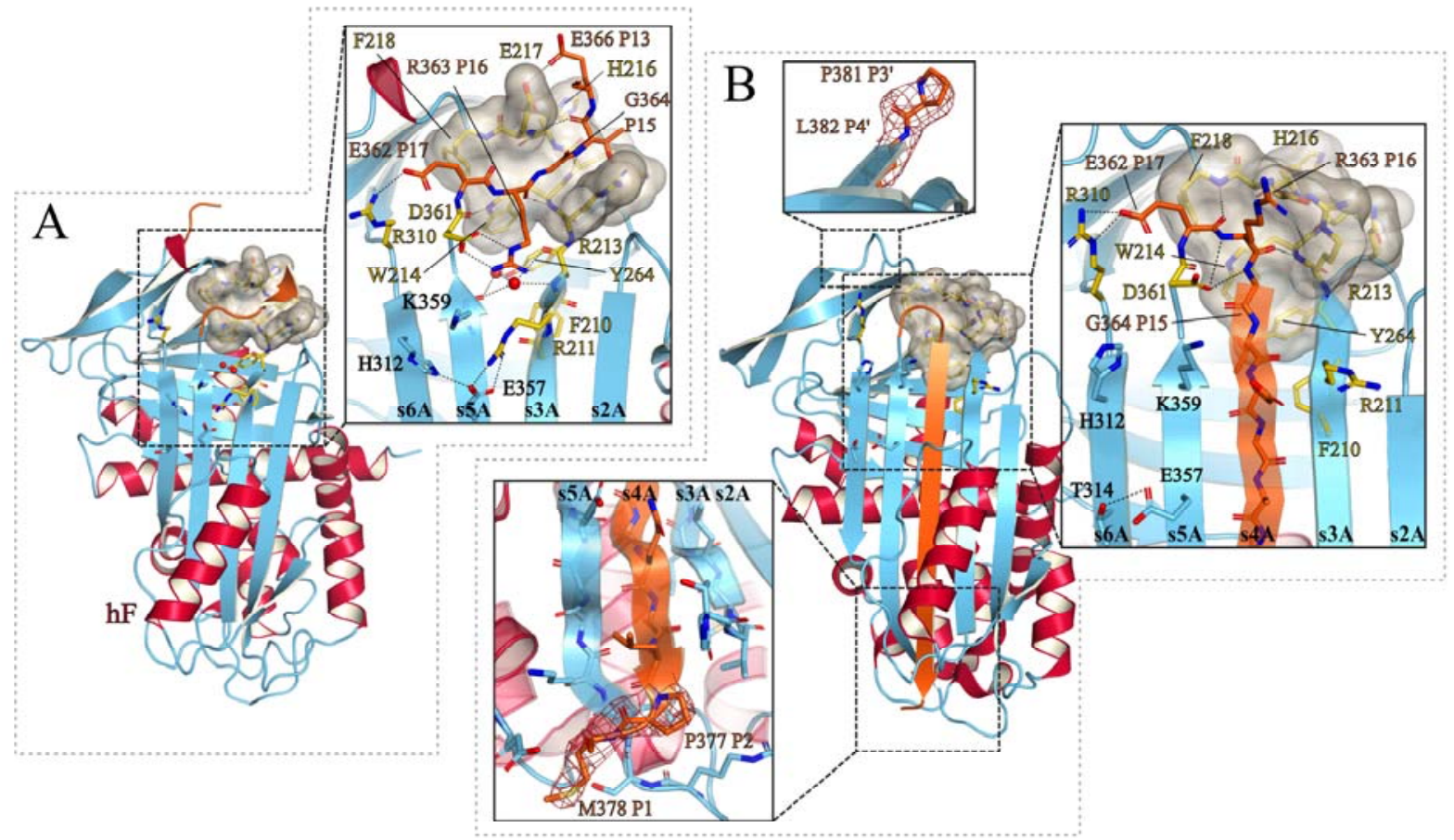

Figure 1 Structural overview and details for native and cleaved vaspin. X-ray structures of native (A, pdb code 4IF8, [17]) and cleaved vaspin (B, pdb code 5EIO, [18]) with close-up presentations for interactions of the breach with the hinge region (middle box) and for selected residues of the inserted RCL (upper and lower box). Residues of the breach region are shown in yellow. Residues of the hinge region together with the $\mathrm{RCL}$ are depicted in orange. The groove is shown as grey surface. $2 \mathrm{Fo}-\mathrm{Fc}$ electron density (contoured to $1 \sigma$ ) for selected RCL residues is shown as red mesh. Of note, in the closed-up presentations, helix $\mathrm{F}(\mathrm{hF})$ was hidden for clarity and viewing angles were slightly changed compared to the presentation of the complete molecules. Figures were generated using PyMOL. 


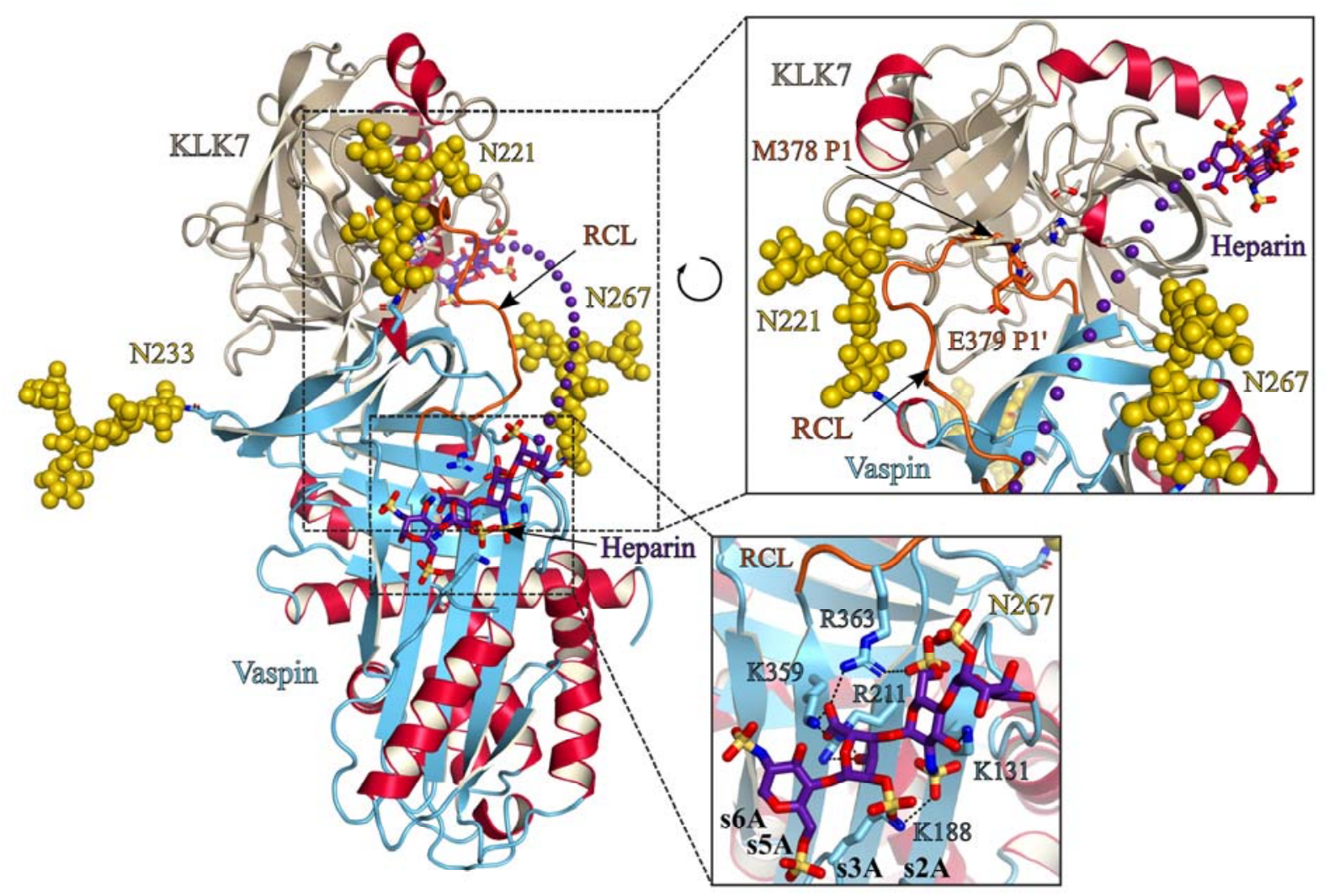

Figure 2 Model of the non-covalent Michaelis-complex between KLK7 and N-glycosylated vaspin bridged by heparin. Interaction of KLK7 (pdb code 2QXI, [158]) and vaspin (pdb code 4IF8, [17]), as well as heparin binding modes for both proteins were modeled using the ClusPro web server [159] and both tetrasaccharides were connected by a dashed line indicating binding of a long-chained heparin bridging both proteins. KLK7 is colored in grey and red whereas vaspin is colored in blue and red. Nglycosylation and heparin tetrasaccharides are presented as yellow spheres and purple sticks, respectively. Close-up presentations show models of vaspin N-glycosylation near the RCL (N221 and N267; yellow) (upper box) as well as the binding mode of a heparin tetrasaccharide to basic residues of $\beta$-sheet $A$ in vaspin (shown as blue sticks, lower box). $\mathrm{N}$-glycosylation was generated using the NetNGlyc 1.0 web server [160] and the structure was produced with GlyProt [161]. The RCL of vaspin was constructed by homology modelling based on a template RCL structure (pdb code 1UHG [162]) and is shown in orange with residues $\mathrm{P} 1$ and $\mathrm{P} 1$ ' shown as sticks. Residues of the catalytic triad in KLK7 are shown as grey sticks. Of note, in the close-up presentations, viewing angles were changed compared to the presentation of the complete molecules. Figures were generated using PyMOL. 


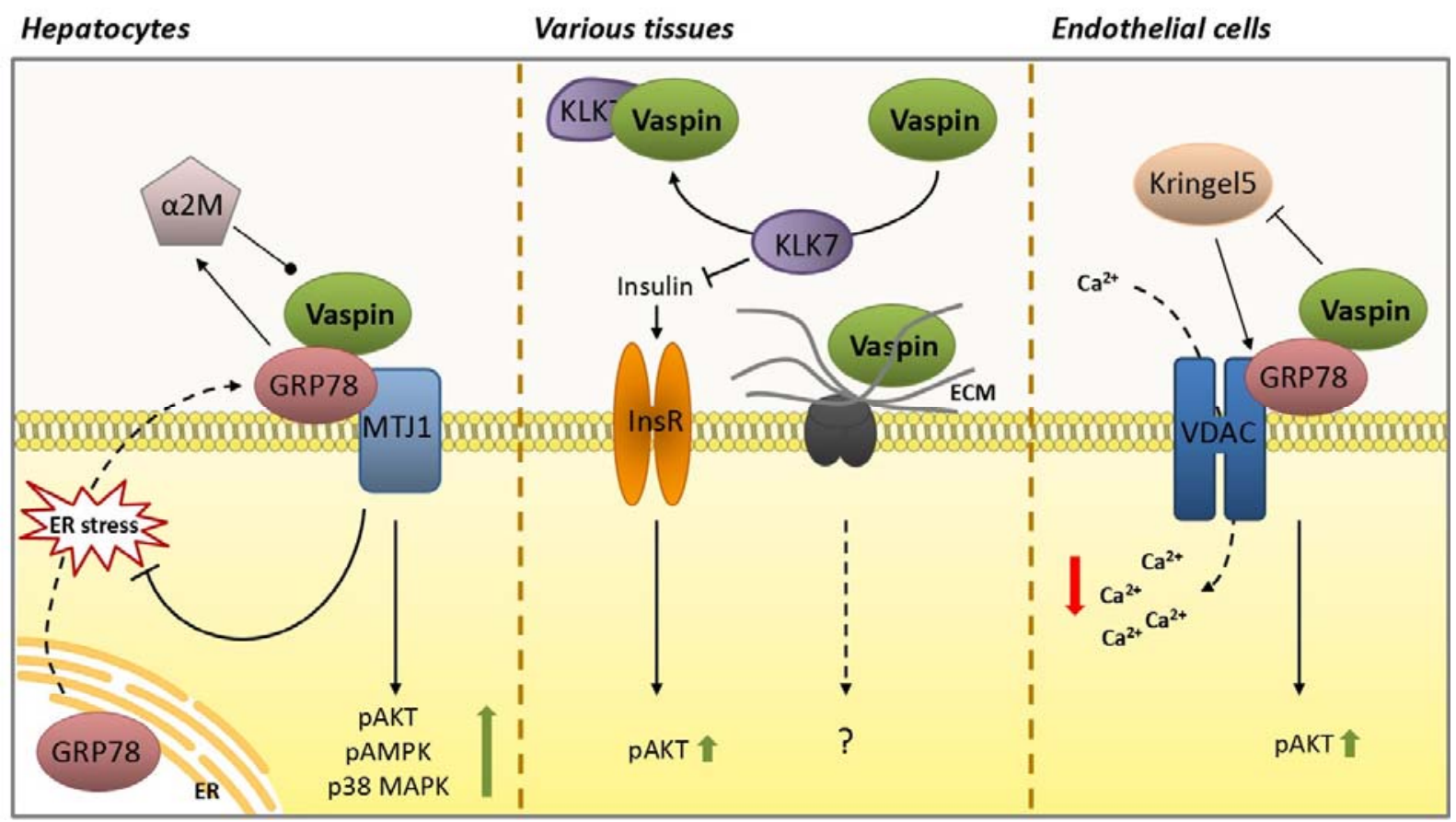

Figure 3 Molecular interactions of vaspin and tissue specific signaling. Direct interactions of vaspin with the GRP78 / MTJ1 complex provoke intracellular signaling cascades such as AKT, AMPK and MAPK in hepatocytes. This interaction also ameliorates ER stress response by inhibiting the translocation of GRP78 from the ER to the plasma membrane. Inhibition of the insulin-degrading enzyme KLK7 via the serpin mechanism is linked to increased insulin signaling and localization of vaspin in the ECM may direct vaspin interaction with ECM or cell surface proteins in various tissues. In endothelial cells, vaspin exerts anti-apoptotic effects by preventing Kringel5 binding to the GRP78/VDAC complex, impeding the increase of intracellular $\mathrm{Ca}^{2+}$ levels. Vaspin-mediated activation or inhibition of pathways or molecules is indicated by green or red arrows, respectively. $\alpha 2 \mathrm{M}$ : alpha-2 macroglobulin. 


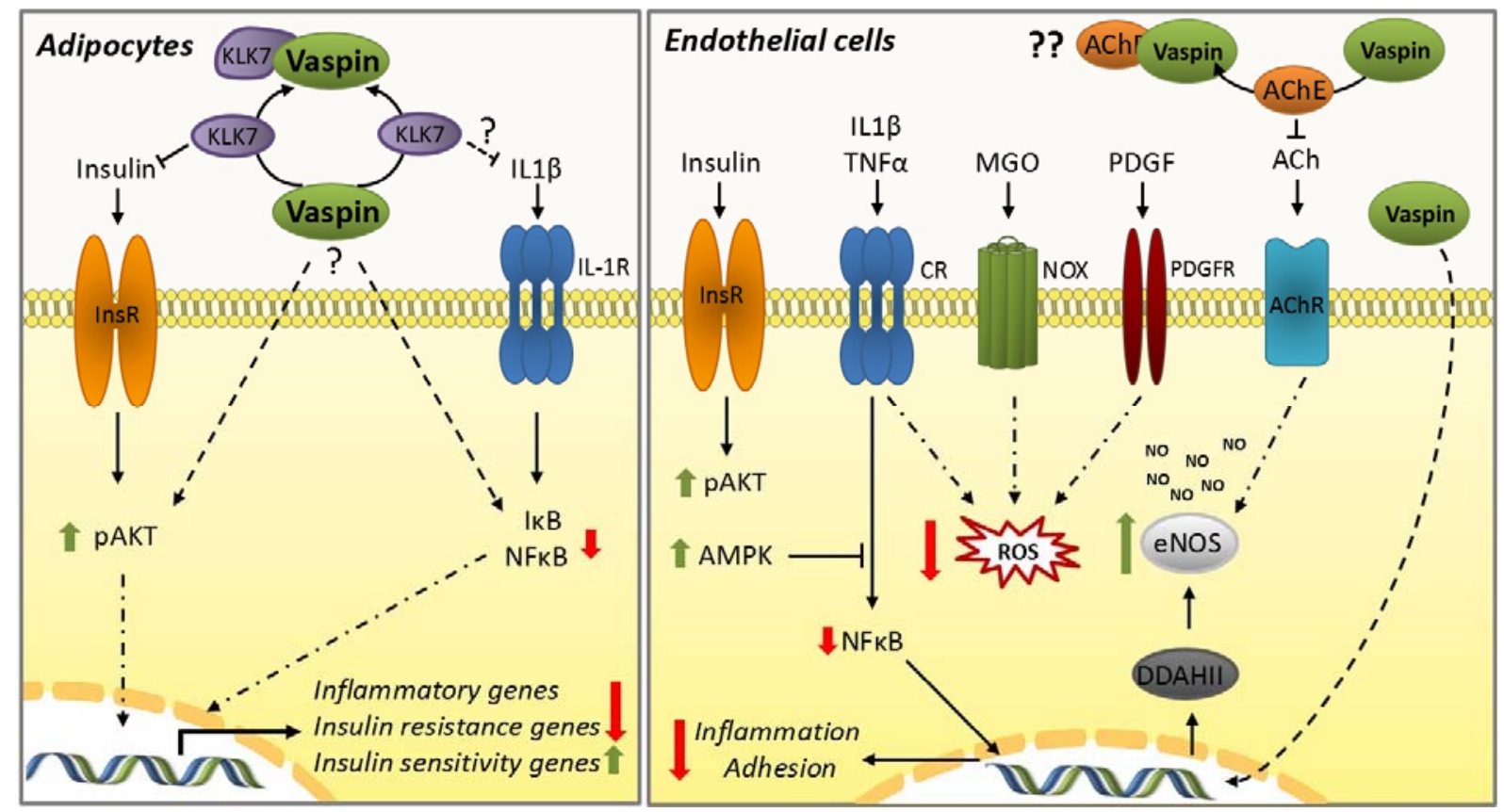

Figure 4 Vaspin induced intracellular signaling in AT and vascular cells. In adipose tissue, vaspin improves insulin sensitivity and decreases inflammatory gene expression in WAT by enhancing AKT phosphorylation and it blunts cytokine-induced NF-KB signaling by reducing phosphorylation of the NFKB-inhibitor IKB (and upstream kinase IKK $\alpha / \beta$ ). Inhibition of KLK7 activity may underlie and contribute to both effects. Insulin signaling is also enhanced by vaspin in endothelial cells at the level of AKT phosphorylation. In parallel, ROS formation through inflammatory cytokines, MGO and PDGF, is reduced and NF-KB signaling is repressed. This leads to a decrease in gene expression of inflammatory and adhesion molecules. Furthermore, intracellular NO bioavailability is increased by vaspin through enhanced expression of DDAHII and increased AKT signaling. It is speculated, that vaspin may inhibit AChE via the serpin mechanism culminating in enhanced ACh-induced eNOS activation. Vaspinmediated activation or inhibition of pathways or molecules is indicated by green or red arrows, respectively. AMPK: AMP-activated protein kinase; CR: cytokine receptor; NOX: NADPH oxidase (NOX); MGO: methylglyoxal; PDGF: platelet-derived growth factor (PDGF); PDGFR: PDGF receptor; ROS: reactive oxygen species; ACh: acetylcholine; AChE: acethylcholine esterase; AChR: ACh-receptor; eNOS: endothelial NOS; DDAHII: dimethylaminohydrolase II. 


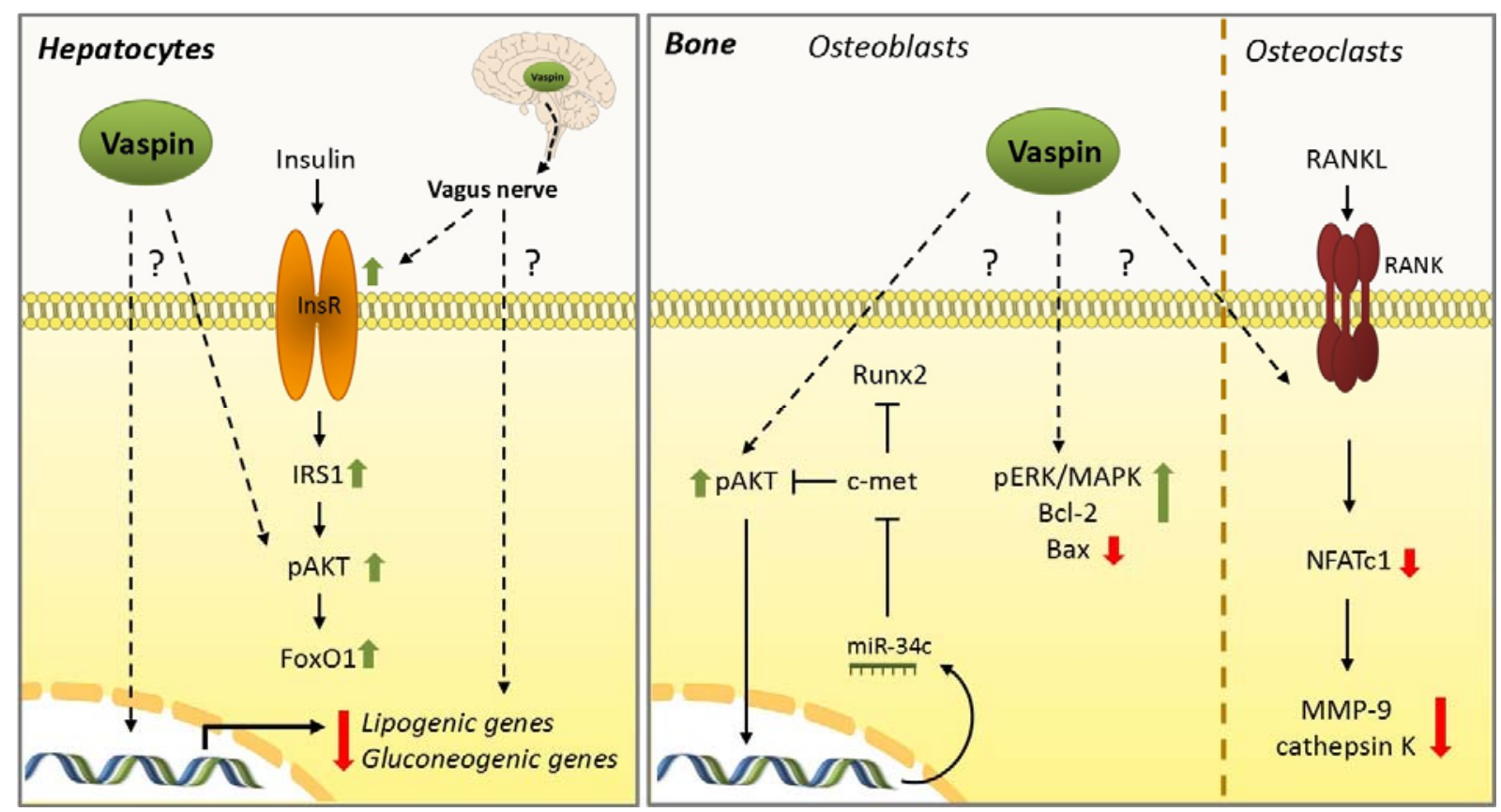

Figure 5 Vaspin induced intracellular signaling in liver and bone. Vaspins central effects are relayed to the liver via the hepatic branch of the vagus nerve to decrease hepatic glucose flux, i.e. by reducing lipogenic and gluconeogenic gene expression and also activation of the insulin signaling cascade in hepatocytes. In bone, vaspin regulates bone remodeling by affecting bone-forming osteoblast as well as bone-resorbing osteoclast. RANKL-induced osteoclastogenesis is diminished via decreased expression of the key mediator NFATC1 and accompanied by a decreased expression of the proteases cathepsine $\mathrm{K}$ and MMP-9. In osteoblasts, vaspin enhances PERK/MAPK signaling and prevents apoptosis by induction of anti-apoptotic $\mathrm{Bcl}-2$ and lowering of pro-apoptotic Bax protein expression. Vaspin also attenuates osteogenic differentiation via a PI3K-AKt/miR-34c signaling loop. Vaspinmediated activation or inhibition of pathways or molecules is indicated by green or red arrows, respectively. 


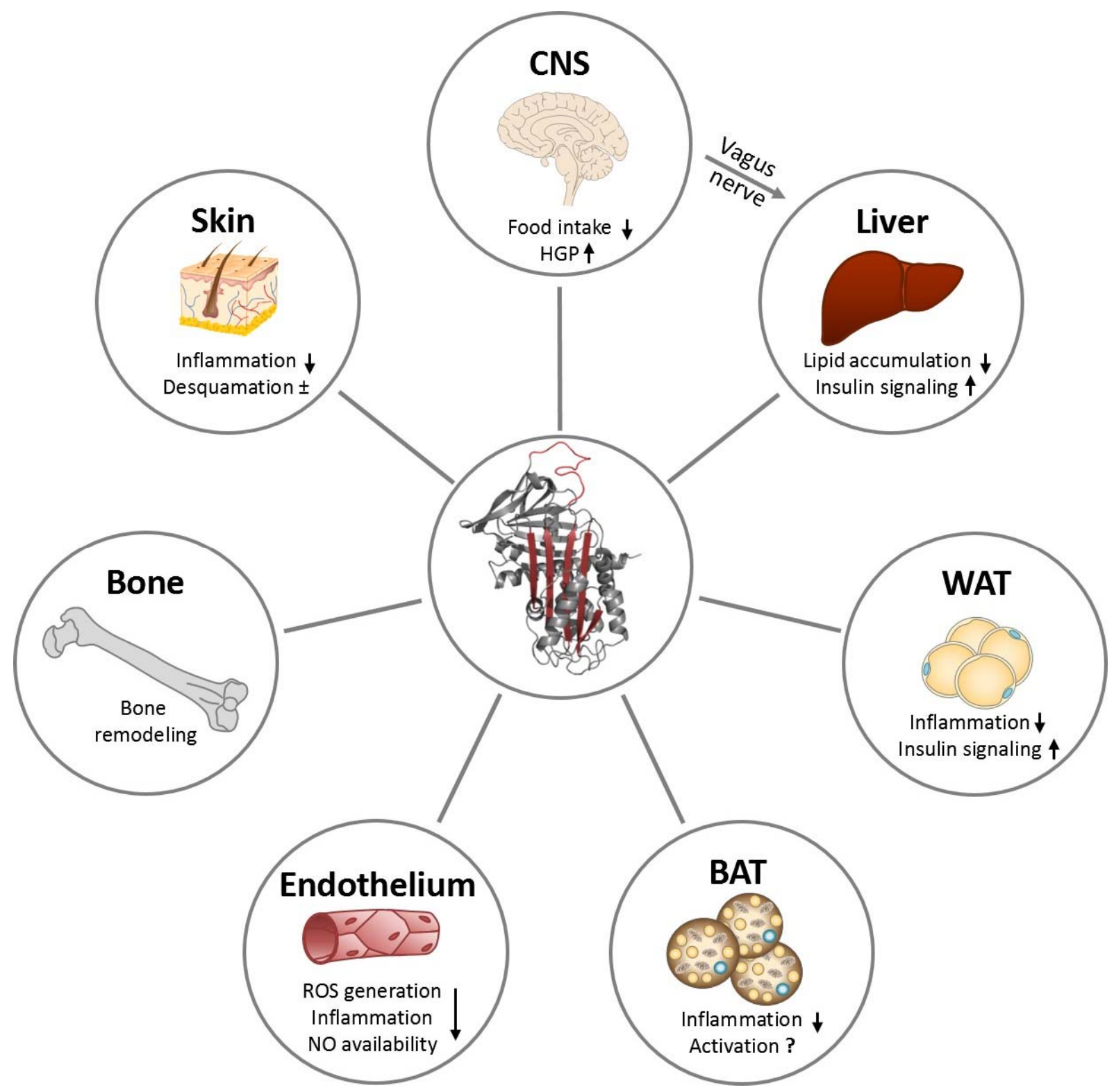

Figure 6 Beneficial effects of vaspin in different tissues and organs that counteract obesity-induced inflammation, insulin resistance and other associated diseases. Central vaspin (application) attenuates food intake and reduces hepatic glucose production (HGP) via the hepatic branch of the vagus nerve accompanied by reduced hepatic lipid accumulation and increased insulin signaling in the liver. In white adipose tissue (WAT), vaspin reduces inflammation and enhances insulin signaling and vaspin expression in brown adipose tissue (BAT) is specifically upregulated upon BAT-activating stimuli. Vaspin counteracts endothelial dysfunction via the combination of its anti-inflammatory effects and by reducing ROS generation while enhancing NO availability. In bone, vaspin modulates bone formation via the regulation of osteoblasts and osteoclast while in skin vaspin alleviates inflammatory processes and affects desquamation by regulating the activity of its target protease KLK7. CNS: central nervous system. 